\title{
Monazite Placers in the
}

\section{Southeastern Atlantic States}

G E O L O G I C A L S U R V E Y B U L L E T I N 11390 
- $x$

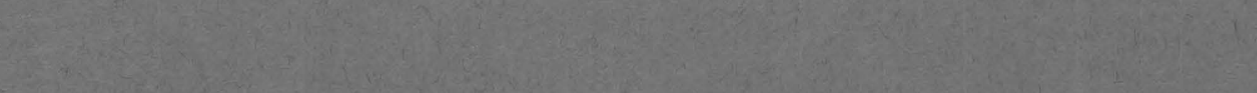

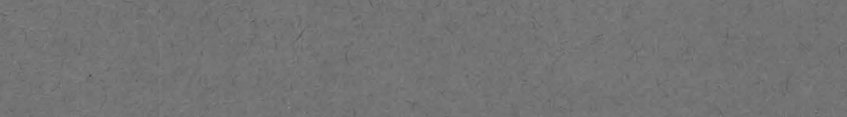




\section{Monazite Placers in the}

\section{Southeastern Atlantic States}

By JOHN B. MERTIE, JR.

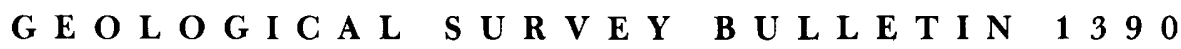

Mountain streams need exploration, but the main placers are likely

to be in the Coastal Plain

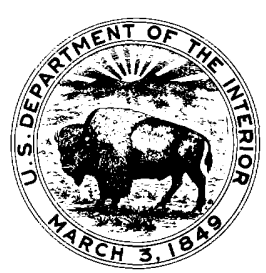




\section{UNITED STATES DEPARTMENT OF THE INTERIOR \\ ROGERS C. B. MORTON, Secretary}

GEOLOGICAL SURVEY

V. E. McKelvey, Director

Library of Congress Cataloging in Publication Data

Mertie, John Beaver, 1888-

Monazite placers in the southeastern Atlantic States.

(Geological Survey Bulletin 1390)

Bibliography: $p$.

Supt. of Docs. no.: I 19.3.1390

1. Monazite-Southern States. 2. Hydraulic mining.

I. Title. II. Series: United States Geological Survey Bulletin 1390.

QE75.B9 No. 1390 [TN948.M7] 557.3'08s

$\left[553^{\prime} .4943^{\prime} 0975\right] \quad 74-14705$

For sale by the Superintendent of Documents, U.S. Government Printing Office Washington, D. C. 20402 - Price 80 cents (paper cover)

Stock Number 024-001-02603 


\section{CONTENTS}

Page

Common measures and their metric equivalents _-

Abstract _-_-_-_-_-_-_._-

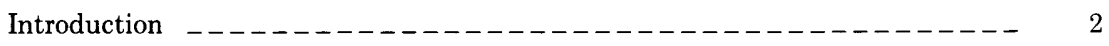

Purpose of present report

Other investigations

Rare-earth minerals and uses _-

Sources of monazite $----------------------4 \quad 4$

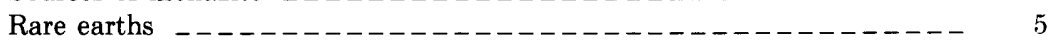

Alluvial monazite $---------n------------1$

Piedmont province $-------------\ldots-----------\quad 7$

Coastal Plain province

General geology _-

Deposits of heavy minerals

Sources _-

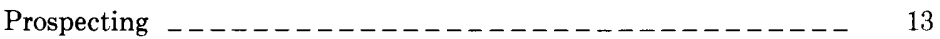

Exploration under the present investigation

Genetic interpretation _- - - - - - -

Placer mining _-

South Carolina _--------------------- 25

Florida _- - -

Conclusions _- - - -

References cited ------------------------------- 38

\section{ILLUSTRATIONS}

FIGURE 1. Map showing configuration of the three monazite belts in the Southeastern Atlantic States in relation to the inner edge of the Coastal Plain

2. Map showing distribution of monazite-bearing samples from the Coastal Plain of South Carolina

3. Map showing distribution of monazite-bearing samples from the Coastal Plain of Georgia

4-9. Photographs:

4. The Perry bucket dredge, operating in the valley floor of Horse Creek, Aiken County, S. C. _.

5. Suction dredge of the National Lead Co., Duval County, Fla.

6. Battery of Humphrey spirals at the plant of the National Lead Co., Duval County, Fla.

7. Concentrating plant of Humphrey spirals on a barge, at the southern plant of the E. I. duPont de Nemours and Co. in Clay County, Fla.

8. Suction dredge of the E. I. duPont de Nemours and Co., at the southern plant, in Clay County, Fla.

9. Aerial view of the dredge, separatory plant, and offices of the Florida Minerals Co., Indian River County, Fla. ....- 


\section{TABLES}

TABLE 1. Locality and description of samples from the Coastal Plain, South

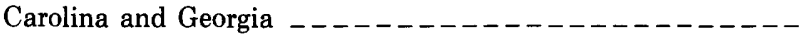

2. Accessory minerals from sedimentary rocks in eight counties,

Coastal Plain of South Carolina _._.

3. Accessory minerals from sedimentary rocks in four counties, Coastal

Plain of Georgia _.-- - -

4. Comparative mean tenors of accessory minerals in crystalline rocks and Pleistocene terraces

5. Sizes of minerals in concentrates from the northern ore body,

National Lead Co. placer, Duval County, Fla

Page

Sizes of monazite grains from the northern ore body, National Lead

Co. placer, Duval County, Fla

7. Composition of minerals and ilmenite products from placer mines in Florida

8. Sizes of heavy minerals in concentrates from Trail Ridge, Fla -

9. Sizes of monazite grains from Vero Beach, Fla.

\section{COMMON MEASURES AND THEIR METRIC EQUIVALENTS}

\section{Common Measure}

Inch

Foot

Yard

Mile

Acre

Cubic yard

Pound, avoirdupois

Ton, long

Ton, short
Equivalent

2.54 centimetres.

0.3048 metre.

0.9144 metre.

1.6093 kilometres.

0.4047 hectare.

0.7646 cubic metre.

0.4536 kilogram.

1.0160 metric tons.

0.9072 metric ton. 


\title{
MONAZITE PLACERS IN THE SOUTHEASTERN ATLANTIC STATES
}

\author{
By JOHN B. MERTIE, JR.
}

\begin{abstract}
Placer mining for monazite in North Carolina and South Carolina in the periods 1887-1911 and 1915-17 was done on small deposits in the headwaters of streams that drained monazite-bearing rocks. Exploration was undertaken in 1951-54 by the U.S. Geological Survey and U.S. Bureau of Mines with the objective of finding larger ore bodies of suitable grade farther downstream that would warrant large-scale mining, but such deposits have not been found. The explanation for the lack of deposits is that a high percentage of the alluvial monazite moves continuously downstream unless it can be held in the interstices of gravel beds. However, the alluvial sediments contain only sparse gravel deposits, because the weathering of most common crystalline rocks in the Southeastern States generally yields only sand, silt, and clay. Exploration is not yet complete, and workable deposits may still be found in valleys where quartzite, chert, crystalline limestone, or other durable rocks are present to produce the thick beds of gravel.
\end{abstract}

That part of the Coastal Plain most likely to have received detrital monazite from the belts of monazite-bearing crystalline rocks in the Piedmont is shown to be in Virginia, North Carolina, South Carolina, Georgia, and Florida. The formations of the Coastal Plain range in age from Cretaceous to Holocene. Distinct Pleistocene terraces are present. The occurrence of monazite in the sedimentary formations of the Coastal Plain is considered, and tables are presented showing the results of panning sedimentary materials from the Pleistocene and some of the Tertiary beds in South Carolina and Georgia. Monazite is generally found in these formations, but the tenors are so low that workable deposits are unlikely. Reconcentration of such deposits by local streams that do not head in the Piedmont province may yield workable placers. A fluvial deposit in Aiken County, S. C., is cited and described as an example of this process.

The Pleistocene terraces are distinguished from one another by their maximum altitudes above sea level. The deposits that form the terraces have well-defined upper limits marked by ancient shorelines, but have no recognizable lower limits. The terraces have been correlated with the several interglaciations of the Pleistocene Epoch, and it is shown that the conditions of weathering, erosion, transportation, and deposition of these sediments were more favorable for the accumulation of heavy minerals during the interglaciations than in Holocene time. Therefore, the largest volume of heavy minerals will be found in the terrace deposits, rather than along the present beaches.

Monazite is generally distributed in all the littoral deposits of Florida, but the content is too low to produce monazite placers. Placers of ilmenite, rutile, and zircon, however, are mined, and at two of the four operating plants, monazite is produced as byproduct. These deposits of heavy minerals, and the methods used in mining them, are briefly described. 


\section{INTRODUCTION}

\section{PURPOSE OF PRESENT REPORT}

A reconnaissance for monazite, an ore of the rare earths and thorium, was made in North Carolina, South Carolina, and Georgia during 194557 (fig. 1). This work consisted mostly of examining and sampling granite saprolites to determine the tenor and character of their accessory minerals. In part, the reconnaissance included an examination of areas where fluvial monazite placers were once mined and the areas where such placers might possibly exist. The investigation of the fluvial placers was begun in the Piedmont of North Carolina in 1945 and was extended to South Carolina in 1948 (Mertie, 1953). In 1951, the study of the fluvial monazite deposits in the western Piedmont of North and South Carolina mainly, but also partly in Georgia and Virginia, became a separate project undertaken jointly by the U.S. Geological Survey and the U.S. Bureau of Mines. Reports on this work have been published (Griffith and Overstreet, 1953a, 1953b, 1953c; Griffith and Theobald, 1953; Hansen and Cuppels, 1954, 1955; Hansen and White, 1954; Hansen and Caldwell, 1955; Hansen and Theobald, 1955; Overstreet and others, 1956; Overstreet and others, 1959; Caldwell, 1962; Cuppels, 1962; Theobald, 1962; White, 1962, Overstreet, 1967; Williams, 1964, 1967; Overstreet and others, 1968; Overstreet and others, 1971; Cuppels and White, 1973; Caldwell and White, 1973).

The formations in the Coastal Plain of South Carolina and Georgia were sampled for detrital monazite by me, in 1948. The investigation of such deposits later became a separate project conducted by Dryden (1958).

I made annual visits, each of a week's duration, to Florida in 1944 and 1945 , and during every year from 1948 to 1957 inclusive, to review the placer mining in that State. Several minerals, including monazite, are recovered in Florida by placer mining operations for ilmenite on the present and the elevated beaches. Increasing industrial demand for titanium assures that placer deposits in Florida and other Southeastern Atlantic States will continue to be an important source of ilmenite for many years. Most of the criteria applicable to the exploration for ilmenite in the Coastal Plain also apply to monazite.

Offshore placer deposits, which have recently attracted interest for monazite, ilmenite, and other heavy detrital minerals (Pepper, 1958; Tanner and others, 1961; Pilkey, 1963; and Emery, 1965), were not studied in this field investigation.

The present report deals with the economic phases of my investigations, during $1945-57$, of monazite in crystalline rocks and placer deposits in the Southeastern Atlantic States. 


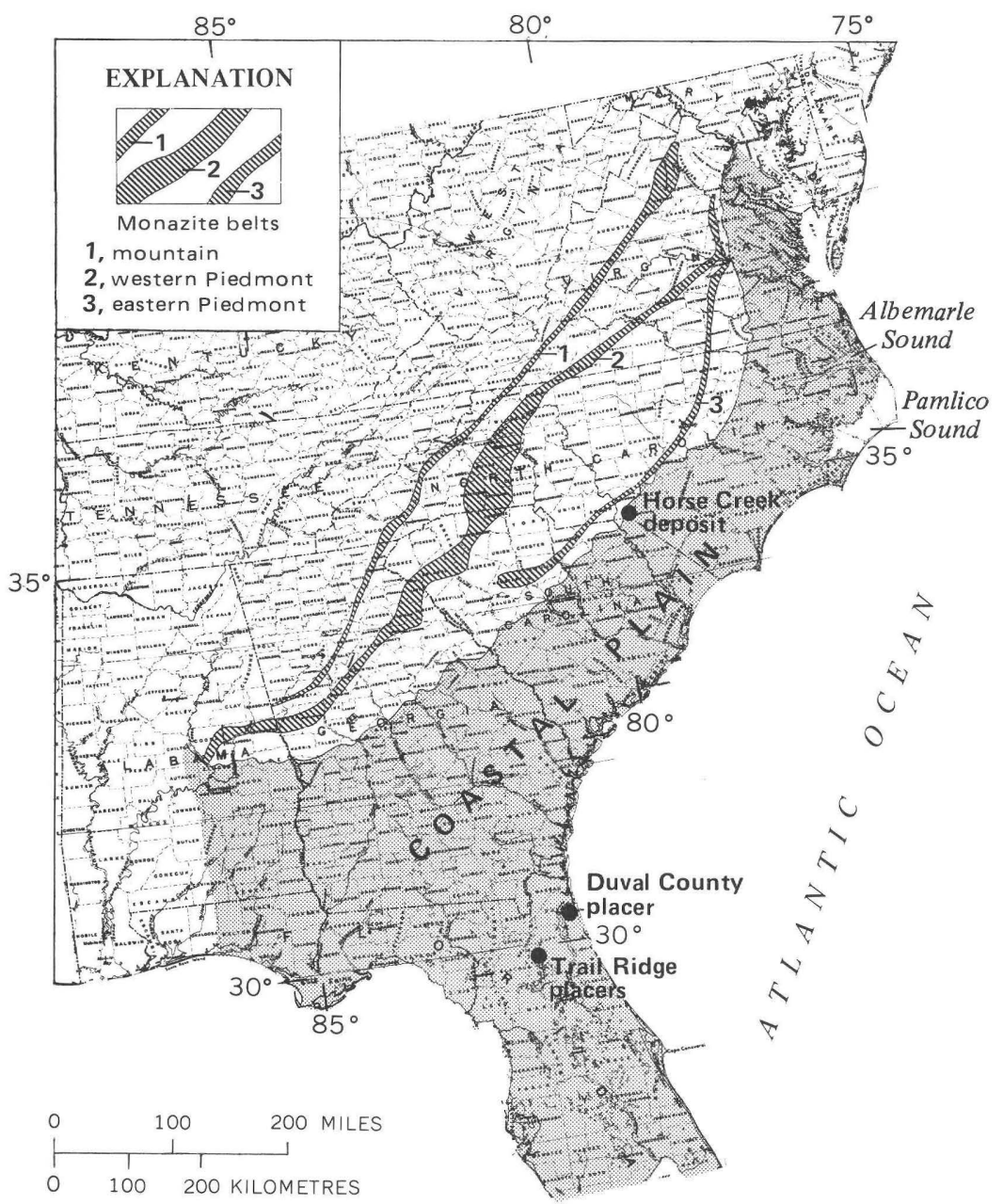

FIGURE 1. - Configuration of the three monazite belts in the Southeastern Atlantic States in relation to the inner edge of the Coastal Plain. Base from U.S. Geological Survey (1970, p. 285).

\section{OTHER INVESTIGATIONS}

The existence of monazite in the Southeastern States has been known since 1849 when its presence in the gold placers of Rutherford County, N.C., was noted by Shepard (1849, p. $275 ; 1852$, p. 109). The literature on monazite in this region is extensive. It was reviewed recently by Overstreet (1967); hence, the older reports will not be summarized here. Material published after that review, however, has been cited where appropriate in the present text. 
Reports up to about 1920 dealt largely with the distribution of monazite in North and South Carolina, the discovery of new deposits, then-current developments in the mining of monazite, and production data. The only deposits of monazite that had economic value were placers, and most of the work centered on these. Since 1925, papers relating to minerals containing the rare earths and thorium have appeared annually in the "Minerals Yearbook" and related publications by the U.S. Bureau of Mines. These do not deal specifically with the monazite of the Southeastern States, but discuss instead the world production and resources of monazite and the uses of the rare earths and thorium. A bibliography of the industrial uses of the rare earths was given by Lamb (1956, p. 743).

The placer deposits in Florida are also the subject of a considerable literature first appearing when sporadic recovery of monazite was made in 1916 and 1917 at the earliest ilmenite mines on the Atlantic coast of the State (Liddell, 1917, p. 153) and continuing through the growth of mining on land and the development of offshore exploration for marine hard minerals (Martens, 1928, Tyler, 1934, Lamcke, 1940; Casperson, 1948; Jones, 1949; Rove, 1952; Carpenter and others, 1953; Calver, 1957; Mertie, 1957; Trumbull and others, 1958; Giese and others, 1964).

\section{RARE-EARTH MINERALS AND USES}

More than 200 minerals are known that contain the rare earths and thorium. Monazite and bastnaesite, however, are the principal sources of the rare earths, and monazite has been the principal source of thorium. Small amounts of xenotime, the yttrian analog of monazite, occur with monazite in the Southeastern States, and may be recovered in mining. In this paper the term "monazite" commonly means both monazite and xenotime.

Monazite was in demand in earlier years mainly for its content of thorium, which was used in the manufacture of Welsbach gas mantles, but beginning in the early part of this century, the rare earths in monazite became progressively more important. A potentially much larger increase in the demand for thorium is found in its use as a fuel in the high-temperature gas reactor power stations now being built in the United States.

\section{SOURCES OF MONAZITE}

Alluvial deposits of heavy minerals that include monazite are known in Brazil, India, Ceylon [Sri Lanka], Burma, Korea, Taiwan, Indonesia, Malaysia, Australia, Egypt [U.A.R.], Nigeria, The Congo (Leopoldville), Uganda, Kenya, Mozambique, Madagascar [Malagasy Republic], Canada, Argentina, and other foreign countries (Overstreet, 1967). The principal producers of detrital monazite are India and 
Brazil, but small outputs are coming from Australia, Ceylon [Sri Lanka], Malaysia, Indonesia, Egypt [U.A.R.], and Korea, mainly as a byproduct from the mining of other heavy minerals. A high-grade lode of monazite, however, was discovered in South West Africa in 1949, and was the principal producer of this mineral during 1952-59 and 1962-63.

Monazite has hitherto been the principal source of thorium, but a new source of this metal has been developed in the Blind River uranium field, in the Elliot Lake area, Ontario, Canada. The lodes worked in this district consist of an ancient conglomerate containing ores of brannerite and uraninite, which are reported by Davidson (1957, p. 670) to contain about 0.11 percent $\mathrm{U}_{3} \mathrm{O}_{8}$ and 0.03 percent $\mathrm{ThO}_{2}$ and are said by Williams (1969) to contain 0.05 percent $\mathrm{ThO}_{2}$. The thorium at first was not saved, but in 1959 the Rio Tinto-Dow Co. built a plant near the Algom Uranium Mines to extract $\mathrm{ThO}_{2}$ from the waste fluids that result in the recovery of uranium.

In the United States, small fluvial placers of monazite were mined in North and South Carolina during 1887-1911, and, sporadically from 1915-17. The richer and more extensive deposits of Brazil and India, that were discovered in 1905 and 1909, respectively, finally rendered the American mining unprofitable. Most of the mining in the Carolinas was done by many operators working on a small scale, but some was done by four larger companies, including one of British and one of German origin. The character and extent of this work, the volume of the production, and the nature of the monazite that was recovered have been reported (Mertie, 1953). The Carolina deposits were not exhausted and, under conditions of a world emergency, could be worked again if necessary.

Alluvial monazite is widely distributed in Idaho, and monazite placers have been worked near Cascade, in Valley County. Monazite-bearing gold placers also occur at many localities in the Boise basin and northward within the area of the Idaho batholith. A small output has come from these sources in Idaho. A small production of monazite results as a byproduct in the mining of heavy minerals placers in the Southeastern Atlantic States, mainly from the littoral sands of Florida. A small volume of monazite, together with some xenotime, was also produced from a fluvial placer in Aiken County, S.C. Most of the monazite used in the United States, however, is imported.

\section{RARE EARTHS}

The name "rare earths" was given during the 18th century to some highly refractory and basic oxides, at the time considered to be elements, that were found during chemical studies of unusual pegmatite minerals. In time the true identity of these perplexing oxides was resolved and a host of new "rare-earth" elements was discovered (Weeks, 1956, p. 695-727). 
In modern usage, the rare earths include the 15 elements from lanthanum (atomic number 57) to lutetium (atomic number 71) which are calied the lanthanide group, together with yttrium (atomic number 39). All or nearly all these elements, except promethium (atomic number 61), can expectably be found together in nature, although some may be much more abundant than others. Minerals containing these elements commonly are characterized by particular suites of the rare earths that are dominated by either cerium or yttrium and consist of the following elements:

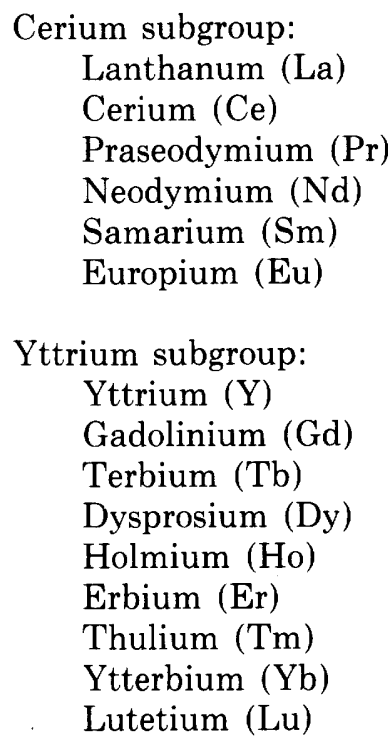

Monazite, a phosphate of the rare earths and for many years their most important ore mineral, contains largely cerium subgroup elements but may also contain appreciable yttrium and some of its subgroup lanthanides as well. The other important ore mineral, bastnaesite, a rare-earth fluocarbonate, is almost exclusively a cerium subgroup mineral. Minerals that contain primarily yttrium subgroup rare earths are not as common but are represented by the phosphate xenotime which is a commercial source of yttrium.

Monazite, in addition to rare earths, commonly contains both thorium and uranium. The $\mathrm{ThO}_{2}$ content of the mineral may range from 0 to 31.5 percent (Overstreet, 1967, p. 1); but these extremes are rare, and from analyses of commercial concentrates, it appears that most monazite will contain from 3.5 to 9.0 percent $\mathrm{ThO}_{2}$ (Parker and Baroch, 1971, p. 67). The uranium content of monazite is generally below 1 percent $\mathrm{U}_{3} \mathrm{O}_{8}$.

The tenor of $\mathrm{ThO}_{2}$ in the monazite of the Southeastern States is well 
known. Fifty-three samples of alluvial monazite from the Piedmont of the Carolinas and Georgia were analyzed for their tenors in thoria by Frank C. Grimaldi and coworkers of the U.S. Geological Survey (Mertie, 1953). Thirty-six of these samples came from North Carolina, with 22 from Cleveland County, 9 from Rutherford County, 3 from Burke County, 1 from McDowell County, and 1 from Alexander County. Sixteen samples came from South Carolina, comprising 11 from Cherokee County, 1 from Spartanburg County, and 4 from Greenville County. One sample came from Spalding County, Ga. The maximum, minimum, and mean tenors in thoria were found to be $7.8,2.5$, and 5.67 percents, respectively. Subsequently, 126 similar analyses of monazite from bedrock in Cleveland and Rutherford Counties, N.C. (Overstreet and others, 1963, table 4) were made by K. J. Murata and H. J. Rose, Jr., of the U.S. Geological Survey. The maximum, minimum, and mean tenors of thoria in the monazite from bedrock were found to be 11.2, 2.1, and 5.5 percents, respectively. The results of these 179 analyses agree remarkably well and tend to show a fairly uniform mean tenor in thoria.

The tenors of $\mathrm{U}_{3} \mathrm{O}_{8}$ in 53 samples of alluvial monazite from the Southeastern States were also determined by Frank C. Grimaldi and coworkers (Mertie, 1953). The maximum, minimum, and mean tenors were found to be $0.98,0.18$, and 0.38 percents, respectively. Later, 10 samples of monazite from saprolitic bedrock in the Shelby quadrangle, North Carolina, collected by W. C. Overstreet, were analyzed for $\mathrm{U}_{3} \mathrm{O}_{8}$ by Carmen Johnson and Blanche Ingram of the U.S. Geological Survey. The maximum, minimum, and mean tenors were found to be 1.48, 0.06, and 0.54 percents (Overstreet and others, 1963, table 5). These results are in general agreement. Subsequently, tenors in $\mathrm{U}_{3} \mathrm{O}_{8}$ as high as 2.34 percent have been reported for monazite from North Carolina (Overstreet and others, 1970).

\section{ALLUVIAL MONAZITE PIEDMONT PROVINCE}

Fluvial monazite is present in all the valleys of the Piedmont province that drain the monazite belts (Mertie, 1953, pl. 1), but is most plentiful in their extreme headwaters. Downstream, the fluvial deposits contain progressively less monazite and in the larger trunk valleys, this mineral is found only in traces.

The monazite placers that were mined in the Southeastern States in the years 1887-1911 and 1915-17, were located in the headwaters of streams that drained monazite-bearing rocks. The sites of these placers were in the widest parts of the monazite belt in the western Piedmont where the host rocks have a high content of monazite. Such placers were commonly formed within a period of a few years, as indicated by the fact that headwater stretches of many streams were mined repeatedly over a period of 20 years. 
Monazite has a density of 4.6 to 5.4 and therefore is concentrated to some degree in the lower levels of alluvium, but most of it continues to move downstream with the other fluvial materials. If the alluvium contains beds of gravel, then the monazite can be held in the interstices. The source rocks of monazite, however, weather in the southern regions into sand, silt, and clay, and thus yield little or no broken bedrock that will produce gravel. Even where broken granitic or gneissic bedrock is present in the headwaters of streams, it is weathered and vulnerable to disintegration; therefore, it does not withstand fluvial transportation and is not abundant farther downstream. Consequently, unless the monazite-bearing bedrock and associated feldspathic country rock contain a large volume of vein quartz, or unless other rocks such as chert or quartzite that are immune to weathering occur in the drainage basins, extensive beds of monzite-bearing gravel will not be formed. In addition, the overall tenor of monazite in downstream placers will be diminished by the influx of fluvial materials from tributary valleys that do not contain monazite.

Headwater placers do not have sufficient volume of sediment to be workable on a large scale, so the commercial placers must be sought downstream. Unfortunately, the grade of the downstream deposits is too low, and, as yet, monazite placers that can be worked on a large scale have not been discovered in the Piedmont province. Minerals of higher density than monazite, such as cassiterite $(d=6.8-7.1)$ and wolframite ( $d=7.1-7.5)$, move less readily downstream, and where they are from bedrock sources of equal tenor are more likely to produce workable placers.

I panned many of these small placers in North and South Carolina (Mertie, 1953, p. 10). In 52 samples I determined that the tenors of the workable gravel and sand ranged from 4.2 to 85.6 pounds of monazite to the cubic yard, with a mean value of 18 pounds per cubic yard. Few of the deposits were worked to depths in excess of 3-4 feet, and the widths were those of the narrow valley floors. During the period 1900-06 many men were engaged in the mining of these small deposits, mainly in groups of one to three men (Mertie, 1953, p. 6). The monazite was recovered by sluicing, and to judge from some old equipment seen in South Carolina, a single 12-foot sluice box, about 20 inches wide and without riffles, was set at a grade of about 1-2 inches in 12 feet. Above the upper end of the box a 3-foot-long piece of sheet iron perforated with $3 / 8$-inch holes acted as a grizzly. Gravel and sand were shoveled onto this iron plate, and after being washed, the coarse gravel was removed by shovels and pitchforks. Fine gravel, sand, silt, and clay passed through the holes; most of the finer alluvial material, including some of the monazite, was washed out of the box. Monazite recovery must have been exceedingly low. Sluice water came from behind a small dam that was made upstream from the ground to be worked. The work progressed 
upstream, and as one block of ground was exhausted, a new dam was built.

A few deposits were worked farther downstream by larger operators, but the limits of these deposits were set by diminishing tenors. As terraces are present along most of the streams in this region, monazite placers may also exist in them. Few such deposits were worked owing to difficulty of reaching them with sluice water.

The concentrates consisted chiefly of ilmenite, monazite, magnetite, and small amounts of other minerals such as garnet and zircon. Only the few larger operators had electromagnets used to separate the monazite from the other minerals; therefore, the small operators would sell their concentrates to these large operators. The sales price was determined by the amount of monazite recovered from the concentrates and ranged from 20 to 80 percent of the market price for pure monazite, which then was about 15 cents a pound. A high-grade monazite product could not be obtained simply by magnetically separating ilmenite and other magnetic minerals from monazite. A higher grade product could be obtained, however, by increasing the magnetic field, but some of the monazite was then separated with the ilmenite fraction. Such losses were common, as I verified by checking the ilmenite tailings at the old refining plant of the German-American Monazite Co. on the headwaters of Sandy Run Creek, northeast of Ellenboro, Rutherford County, N.C. Xenotime appears not to have been recognized, and doubtless most of it was lost with the ilmenite fraction.

Exploratory work was begun in 1951 by the U.S. Geological Survey and the U.S. Bureau of Mines. The primary objective was the location of monazite placers within the western Piedmont monazite belt (fig. 1) in North Carolina, South Carolina, and Georgia that could be worked at a profit by modern mining methods (Overstreet and others, 1968). Such methods are costly and entail the purchase, installation, and eventual amortization of expensive mining and separatory equipment. Deposits must be of suitable grade and large enough to insure adequate financial return over a period of 15-20 years. The geologic conditions that prevail in this region are generally unfavorable for the formation of monazite placers of the required volume and grade, although placers of low grade and large volume and of higher grade and smaller volume have been found.

The economic results of this exploratory work apply only to the alluvial deposits of the western Piedmont monazite belt of North and South Carolina and parts of Georgia. The parts of this belt that extend into Virginia and Alabama, the eastern Piedmont monazite belt, and the mountain monazite belt (fig. 1) have not been thoroughly explored. Some of these deposits were investigated where mining had formerly been done, and some areas were studied where the tenor of monazite in bedrock was most favorable. The existence of placers depends not so much upon the tenors of source rocks as upon the conditions of alluvial 
accumulation and concentration. High-grade gold placers, such as those in the Klondike district, Canada, have formed in regions where no gold lodes of any consequence have ever been found. Similarly, small, low-grade, monazite-bearing placers in parts of the western Piedmont, eastern Piedmont, and mountain monazite belts are not necessarily indicative of the absence of placers in other parts of the same belts. If lowgrade sources of monazite occur in an area where resistant rocks, such as vein quartz, quartzite, chert, or massive limestone are prevalent, monazite placers could develop in gravels derived therefrom. One such possible area is south-southwest of Front Royal, Warren County, Va. There gravels are produced from the Beekmantown, Conococheague, and Elbrook Limestones in the tributaries of the South Fork Shenandoah River that head in an area of monazite-bearing Pedlar Formation (Bloomer and Werner, 1955).

\section{COASTAL PLAIN PROVINCE}

\section{GENERAL GEOLOGY}

The Coastal Plain lies along the Atlantic coast of the United States from Long Island, N.Y., south to Florida and west along the Gulf of Mexico to Texas. It extends northward in the Mississippi embayment to southern Illinois. The part of the Coastal Plain that is most likely to have received monazite from the three monazite belts (fig. 1) is in Virginia, North Carolina, South Carolina, Georgia, and Florida. Monazite has been identified in the Cretaceous sedimentary rocks and in four of the seven Tertiary formations of the Coastal Plain in South Carolina (Overstreet, 1967, p. 252-255), and I have found it in sediments on eight Pleistocene terraces in the State. From oldest to youngest, the terraces are: the Hazlehurst, Coharie, Sunderland, Okefenokee, Wicomico, Penholoway, Talbot, and Pamlico. Monazite is present in the Cretaceous and Tertiary sedimentary formations in the western part of the Coastal Plain in Georgia (Overstreet, 1967, p. 136-138), and I found the mineral in sediments on the Penholoway, Talbot, and Pamlico terraces. Commercial deposits of heavy minerals that include monazite have been mined in South Carolina and are being mined in Florida and Georgia.

The principal rivers, which drain the three monazite belts, are the Roanoke in Virginia, the Pee Dee in North Carolina, the Santee and Savannah in South Carolina, and the Altamaha and Flint in Georgia. All generally drain southeastward except the Flint River which drains generally southward. Accessory minerals of the crystalline rocks of the Piedmont and Blue Ridge provinces occur in all the streams that drain these areas. Some of the accessory minerals remain in the fluvial deposits, but most of them migrate downstream and eventually become a part of the Coastal Plain littoral deposits at or near strandlines that 
existed at the time of their formation. Heavy minerals were concentrated locally when many of these littoral deposits were subsequently modified by the action of winds, waves, and coastwise currents. Alluvial deposits at or near the present and older strandlines are the principal commercial sources of heavy minerals.

The formations of the Coastal Plain range from Cretaceous to Holocene in age. The Tuscaloosa Formation, of Late Cretaceous age, is the basal formation in Alabama, Georgia, and the Carolinas, overlapping the crystalline rocks of the Piedmont province. The younger deposits include formations of Paleocene, Eocene, Oligocene, Miocene, Pliocene, and Pleistocene ages that have different names in different States. Nine Pleistocene terraces in the Atlantic Coastal Plain have been identified by Cooke $(1945$, p. 17,$248 ; 1954$, p. 200-204). The alluvial deposits of these terrraces are distinguished from one another by their maximum altitudes above sea level (base levels of ancient shorelines). Named from highest (oldest) to lowest (youngest), these terraces and their maximum altitudes, in feet, are the Hazlehurst, 270; Coharie, 215; Sunderland, 170; Okefenokee, 145; Wicomico, 100; Penholoway, 70; Talbot, 42; Pamlico, 25; and Silver Bluff, 6.

Although the deposits forming the terraces have well-defined upper surfaces, their lower limits are less clearly defined and may vary considerably in altitude. Thus, the base of a higher terrace locally may be lower than the base of the next younger terrace. For example, a sand or mineral horizon lying between the upper base levels of the Coharie and Sunderland terraces and at or close to the surface would be of Coharie age. If a stratum was located at some depth below the surface, but within the limits of the same base levels, it might be either Coharie or older in age, including possibly Tertiary or Cretaceous.

Single terraces and groups of terraces have been correlated by Cooke $(1945$, p. 17,248$)$ with the several interglaciations of the Pleistocene Epoch. These correlations have a bearing upon the magnitude and tenor of the mineral-bearing littoral deposits. The more readily accessible sands of the Pleistocene terraces probably were deposited in the interglaciations, when base levels were relatively high; and these sands covered the deposits of the preceeding glaciations, when base levels were lower. Added to such oscillations of the strandline, a general uplift of the land bordering the Atlantic Ocean has been in progress since Cretaceous time. All the interglaciations are believed to be much longer than the time that has elapsed since the last major retreat of the glaciers. The climates of the interglaciations were probably milder than those of the glaciations or that of post-Wisconsin time. Thus, the conditions of weathering, erosion, transportation, and deposition of sediments are inferred to have been more favorable for the accumulation of heavy minerals during the interglaciations than in Holocene time. The largest volume of heavy minerals will therefore be found in 
the terrace deposits, rather than along the present beaches. The history of placer mining in Florida bears out this interpretation. Small deposits of heavy minerals have been found and worked on the present beaches, but large ore deposits, aggregating tens of millions of tons, have been located only on the terraces.

The larger deposits of heavy minerals thus may be related to strandlines that existed in the interglaciations, but I would not infer that they are necessarily marine deposits. The general scarcity or absence of marine fossils in the placers contradicts an interpretation of marine origin. Some of these deposits may have been formed along oceanic or estuarine beaches, but most of them probably accumulated as outwash fluvial deposits from streams that debouched onto a wide lowland bordering the ocean. Many have clearly been modified by eolian action.

\section{DEPOSITS OF HEAVY MINERALS}

\section{SOURCES}

All the formations of the Coastal Plain probably received varying amounts of heavy minerals from the crystalline rocks at the time of their deposition. In addition, each formation of the Coastal Plain, except the Holocene sands, has been partly eroded to form younger deposits, which constitute additional potential sources of heavy minerals. In particular, the Tuscaloosa Formation is recognized as a significant proximate source. However, the older formations have been covered to a great extent by younger formations, so they are not readily accessible. Large areas of Pleistocene and Holocene alluvium are more accessible; and such materials, mainly sands, constitute all the local concentrations of heavy minerals that approach or attain a commercial grade.

Monazite makes up only a minor part of the heavy minerals in the Cretaceous and Tertiary formations of the Coastal Plain, but it is recognizable nearly everywhere in sands in the basins of rivers that drain the monazite belts. Although the present courses of such rivers are different from the courses of ancestral streams during the Cretaceous and Tertiary Periods, the areas lying along or closely adjacent to the present or ancestral courses of these rivers are the best sites to prospect for monazite. The ancient courses can be inferred from geomorphic and stratigraphic features in the Coastal Plain.

Few clues are available to help locate the exact sites of deposits of heavy minerals, even when the best general areas are known. Neither the regional topography nor the results of surficial prospecting are reliable indices. In some areas the presence of dunes may be a guide by indicating where mineral-bearing sands may have been modified or further concentrated by eolian action. In addition to the general lack of 
clues, another handicap is that most of the commercial grade deposits found so far, other than those on the present beaches, lie at some distance below the surface of the ground. Although surficial prospecting is not a reliable tool, I have found that the panning of surficial sediments can give a clue to buried deposits, and that the low tenors of monazite above such deposits tend to be somewhat higher than the tenors of monazite elsewhere in the general area. A commercial grade deposit in Georgia was located by this method; and several sites in South Carolina, identified by panning surficial sediment, appear to be worthy of underground exploration. In general, deposits of heavy minerals in the Coastal Plain, except the smaller concentrations on the present beaches, are best discovered and appraised by systematic drilling.

\section{PROSPECTING}

Deposits of heavy minerals are being or have been sought in the Carolinas, Georgia, and Florida by State geological surveys and by private companies, including E. I. duPont de Nemours and Co., and the National Lead Co. The results of the private exploration have not yet been published, but considerable drilling was done in North Carolina north of Albemarle Sound in Chowan, Perquimans, Pasquotank, and Camden Counties; some drilling was undertaken between Albemarle Sound and Pamlico Sound; and some was done in Beaufort and Pamlico Counties, west of Pamlico Sound. These deposits appear to be a part of the Pamlico terrace. The tenors in heavy minerals are thought to be less than commercially acceptable grade. It is not known whether the heavy minerals contain monazite.

In South Carolina prospecting for heavy minerals has been done by the State Development Board (McCauley, 1960) and by private companies. The monazite-bearing fluvial deposit on Horse Creek in Aiken County, S.C., has been mined. The present oceanic beaches of South Carolina, from the North Carolina line to the Georgia line, were prospected during 1958 by Neiheisel (1958a; 1958b; 1959). He noted that the Pee Dee and Santee Rivers are the principal present carriers of heavy minerals.

Prospecting for heavy minerals is being done in Georgia, partly by the Geological Survey of Georgia (Neiheisel, 1962; Smith and others, 1967), but mainly by private companies, particularly those mining placers in Florida. The panning I did (Mertie, 1953, p. 15) in 1948 in Brantley County, Ga., revealed surficial tenors near Hoboken of nearly 1 percent of heavy minerals exemplified by samples $48-\mathrm{Mt}-95$ and 48-Mt-96. Higher grade sands may lie below the surface, and this area may be the northward extension of the paystreak at Trail Ridge, Bradford County, Fla. Subsequently, a large block of ground in Charlton County, south of this area, was prospected and acquired by E. I. duPont de Nemours and Co. 
St. Simons Island in Glynn County, Ga., and Cumberland Island in Camden County, Ga., are known to have been prospected for heavy minerals, and some of the islands between them likely have been prospected. Cumberland Island has been extensively prospected by two or more large companies on behalf of the owners of this island. Owing to the settlement of several estates, the ownership of this island has been in litigation for several years, but recently the mineral deposits are reported to have been acquired by a large paint company. The deposits of heavy minerals on Cumberland Island are said to lie at the center of the island, trending nearly north, at a maximum altitude of about 40 feet, thus corresponding closely to the shoreline of the Talbot terrace. Prospecting has also been done on the mainland in the vicinity of Darien in McIntosh County, Ga.

\section{EXPLORATION UNDER THE PRESENT INVESTIGATION}

Some of the terrace deposits of the Coastal Plain of South Carolina and Georgia were sampled by panning surface material in October 1948. The exploratory work was done along the northeast and southwest sides of the Santee River valley in South Carolina for distances up to 80 miles from the coast. Thirty-nine samples were taken from Pleistocene terraces, and four from Eocene formations. The samples taken in Georgia were collected in the vicinity of the Altamaha and Savannah Rivers, whose headwaters drain one or more of the monazite belts (fig. 1). The samples from Glynn and Brantley Counties came from the valley of the Little Satilla River, not far south of the Altamaha River, and those from Camden and Charlton Counties came from the valley of the Satilla River. The localities are shown in figures 2 and 3 of this report and in an earlier report (Mertie, 1953, pl. 1, fig. 2), and the localities and character of the deposits are described in table 1 . Mineralogical determinations are shown in tables 2 and 3, where the samples are arranged primarily in the order of increasing age of source material.

C. W. Cooke, U.S. Geological Survey, accompanied me on the trip when these samples were taken and he identified the different terraces and formations that are listed. The mineralogical work on these 56 samples was done by Eleanor Thompson and Judith Weiss Frondel, U.S. Geological Survey.

\section{GENETIC INTERPRETATION}

Mineralogically the samples shown in tables 2 and 3 are similar, though the proportions of the several accessory minerals may differ considerably. The mean tenors of the five principal heavy minerals in the Pleistocene terraces and the monazite-bearing crystalline rocks of the monazite belts (fig. 1) are given in table 4 . 


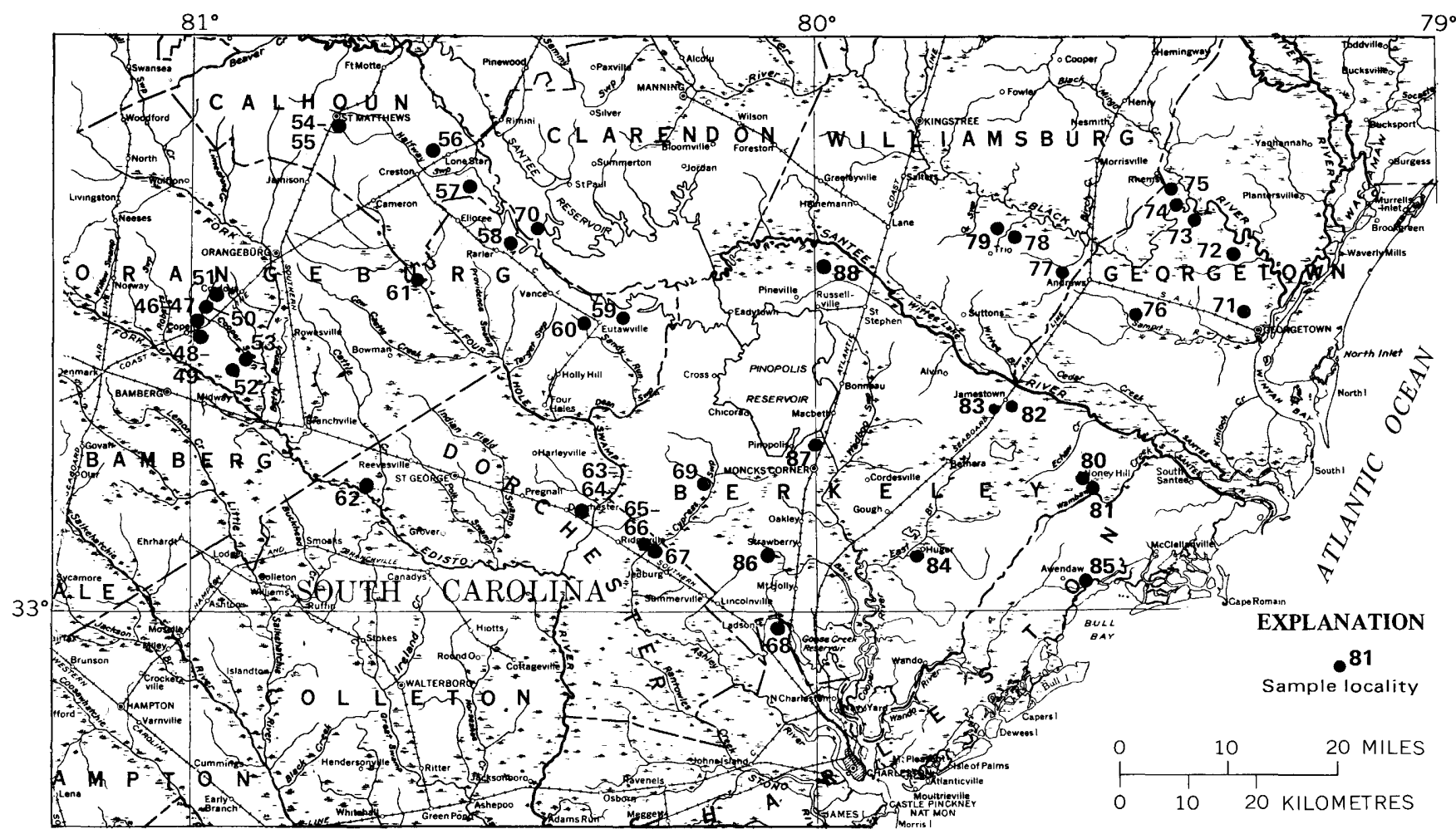

FIfIIRE 2. - Distribution of monazite-bearing samples from the Coastal Plain of South Carolina. Sample localities are those of monazite-bearing concentrates of series $48-\mathrm{Mt}-46$ to $48-\mathrm{Mt}-88$ panned from sedimentary formations of the Atlantic Coastal Plain; descriptions given in table 1. 


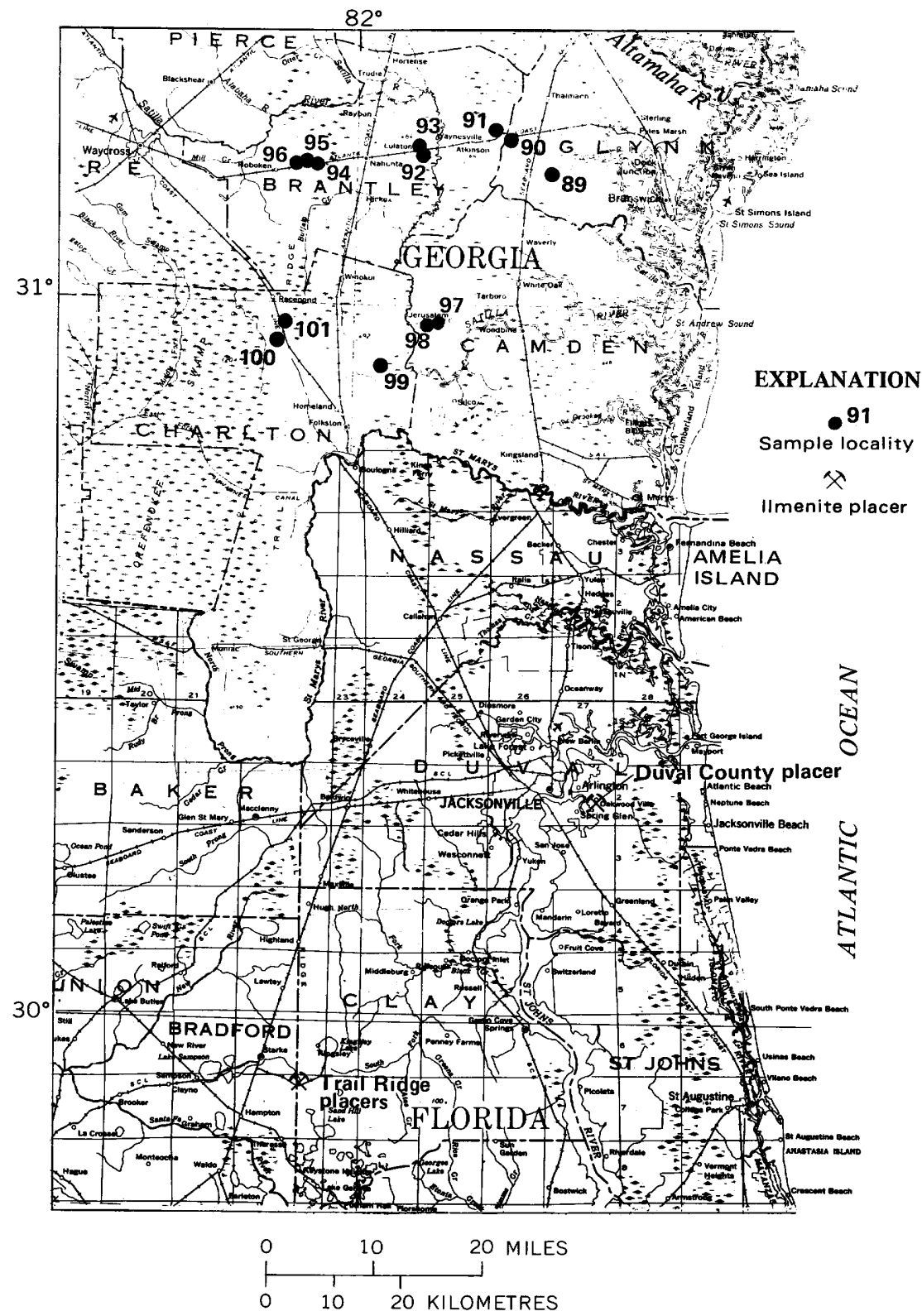

FIGURE 3. - Distribution of monazite-bearing samples from the Coastal Plain of Georgia. Sample localities are those of monazite-bearing concentrates of series $48-\mathrm{Mt}-89$ to 48-Mt-101 panned from sedimentary formations of the Atlantic Coastal Plain; descriptions given in table 1 . 
TABLE 1. - Locality and description of samples from the Coastal Plain of South Carolina and Georgia

Sample

(figs. 2, 3)
Locality and description

Berkeley County, S.C.

48-Mt- 68_ _ _ Ravenels quadrangle. North side of U.S. Highway 78 , about 1.05 miles N. $55^{\circ} \mathrm{W}$. of Otranto Altitude $30 \mathrm{ft}$, Talbot terrace. Semiconsolidated brown sand, in a section $4 \mathrm{ft}$ thick.

$69 \ldots$ Summerville quadrangle. Northeast side of State Highway 31 , about 0.85 mile N. $80^{\circ}$ W. of Wassamassaw Church, on west side of Wassamassaw Swamp. Altitude, $50-60 \mathrm{ft}$. Penholoway terrace. Clayey sand, mottled in tones of red, yellow, and white, in a section $4 \mathrm{ft}$ thick.

$80_{-}$- - Honey Hill quadrangle. Southeast side of State Highway 179 , about $1^{12}$ miles southeast of Honey Hill, and just southeast of the Honey Hill fire tower. Altitude $25 \mathrm{ft}$. shoreline of Pamlico terrace. Light-vellow unconsolidated sand in a section $3 \mathrm{ft}$ thick.

81_. _ Honey Hill quadrangle. West side of State Highway 179, about 0.6 mile southeast of Honey Hill, and 0.83 mile northwest of Honey Hill fire tower. Altitude about $40 \mathrm{ft}$, dune on Talbot terrace. White sand, stained irregularly yellow, in a section $6 \mathrm{ft}$ thick.

$82 \ldots$ _ _ Jamestown quadrangle. East side of State Highway 179, about 1.7 miles southeast of Jamestown. and about $100 \mathrm{ft}$ northwest of junction with Pipkin Road. Altitude $36 \mathrm{ft}$, Talbot terrace. Brown sandy clay, in a section $3 \mathrm{ft}$ thick.

$83_{-}$. J Jamestown quadrangle. Northwest side of State Highway 511, about $1^{1 / 2}$ miles southwest of Jamestown, and just southwest of Tiger Corner Road. Altitude $40-45 \mathrm{ft}$. Talbot terrace (may be Black Mingo Formation). Consolidated red clay containing mica, but no large grains of quartz, from a section $6 \mathrm{ft}$ thick.

84_ _ _ Cordesville quadrangle, in Francis Marion National Forest. East side U.S. Highway 511, about $15^{3}$, miles southwest of Jamestown. Altitude about $35 \mathrm{ft}$, Talbot terrace. Red to orange clay, in a section $10 \mathrm{ft}$ thick.

86_ _ _ Summerville quadrangle. West side of State Highway 64, about 71: miles northeast of Summerville and ${ }^{4}$ mile north of Poplar Branch. Altitude $70 \mathrm{ft}$. Penholoway terrace, bar or dune on Penholoway spit. Light-yellow unconsolidated sand $3 \mathrm{ft}$ thick, underlain by yellow clayey sand. Sample from the light-yellow unconsolidated sand.

$87 \ldots$ - _ Bonneau quadrangle. North side of a secondary road leading from U.S. Highway 52 west to the Santee-Cooper hydroelectric power plant, and 0.7 mile from U.S. Highway 52 . Altitude $50 \mathrm{ft}$. Black Mingo Formation. Section $8 \mathrm{ft}$ thick, overlain by $4 \mathrm{ft}$ of sand of the Penholoway Formation. Black Mingo Formation, from which sample was taken, is a yellow-brown to orange consolidated coarse sandstone and grit, mottled with white spots and stringers.

88 _ _ - Bonneau quadrangle. Northeast side of U.S. Highway 52, about 4 miles northwest of St. Stephens, where a secondary road leads off to west: and about 4 miles southwest of Santee River. Altitude 77 $\mathrm{ft}$, dune near Penholoway shoreline, possibly atop Wicomico terrace. White unconsolidated sand 6 $\mathrm{ft}$ thick. underlain by yellow clayey sand. Sample from white sand.

Calhoun County, S. C.

48.Mt-54_-_ St. Matthews quadrangle. West side of U.S. Highway 21, about $1^{1}+$ miles south of St. Matthews Altitude about $220 \mathrm{ft}$. McBean Formation of middle Eocene age, containing marine fossils. Roadcut $15 \mathrm{ft}$ high. Sample from upper $5 \mathrm{ft}$ of coarse-grained quartzose grit on west side of road.

55. _ _ St. Matthews quadrangle. Same locality as No. 54 . Sample from lower $5 \mathrm{ft}$ of coarse-grained quart zose grit on west side of road.

56 _ _ _ Elloree quadrangle. Southwest side of State Highway 47, about 1.2 miles west-northwest of junction with Belleville Road. Altitude about $230 \mathrm{ft}$, dune behind Coharie terrace. Unconsolidated vellow sand, with darker irregular-shaped masses in 8 -ft roadcut. Sample from lower $6 \mathrm{ft}$ of section.

$57 \ldots$ _ _ Elioree quadrangle. East side of State Highway 47 , about $3^{3}{ }_{4}$ miles S. $23^{\circ}$ E. of Lone Star. Altitude $170 \mathrm{ft}$. Sunderland terrace. A 4-ft section of reddish-brown consolidated sandstone, about twothirds quartz grains and one-third clay.

Charleston County, S. C.

48-Mt- 85_ _ _ Awendaw quadrangle. North side of U.S. Highway 17, about 3 miles east of Awendaw, at Buck Hall fire tower. Altitude $20 \mathrm{ft}$, offshore bar on Pamlico terrace. White to yellow unconsolidated sand, dug from pit $4 \mathrm{ft}$ deep.

\section{Clarendon County, S. C.}

48-Mt- 70_ _ _ Summerton quadrangle. Southeast side of U.S. Highway 15, about 250 yds northeast of Lake Marion (Santee River dam) and 100 yds southeast of highway. Altitude about $100 \mathrm{ft}$, either Wicomico terace or dune on Penholoway terrace. Clayey cream-colored unconsolidated very fine sand, with disseminated specks of iron ores. Sample taken from upper $4 \mathrm{ft}$ of a bluff where material was excavated for causeway across the lake.

Dorchester County, S. C.

48-Mt- 62_-_ St. George quadrangle. Utsey Bluff, on northeast bank of Edisto River, about 5 miles S. $45^{\circ} \mathrm{W}$. of Reevesville, and 0.7 mile southeast of Beulah Church. Altitude $87-95 \mathrm{ft}$, Wicomico terrace. Partly

consolidated gritty sandstone. Commencing at the surface, $8 \mathrm{ft}$ of the bluff was sampled.
$63 \ldots$ - R Ridgeville quadrangle. North side of U.S. Highway 78 , about $22_{2}$ miles east, by north of Dorchester, and 30 yds west of Four Hole Swamp. Altitude $70 \mathrm{ft}$, Penholoway terace. Section: Cooper Marl, overlain by $3 \mathrm{ft}$ of carbonaceous sand, $2^{1}$ : $\mathrm{ft}$ of very carbonaceous sand, $15 \mathrm{ft}$ of yellow sand, of which the lower $12 \mathrm{ft}$ was sampled.

$64 \ldots$ Ridgeville quadrangle. Same locality as No. 63. Sample taken of $2^{1} y$ - $\mathrm{ft}$ bed of carbonasceous sand

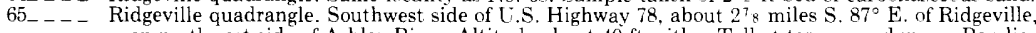
on northwest side of Ashley River. Altitude about $40 \mathrm{ft}$, either Talbot terrace or dune on Pamlico terrace. Sample taken from clayey material that forms the upper $4 \mathrm{ft}$ of an 8 -ft section. 
TABLE 1. - Locality and description of samples from the Coastal Plain of South Carolina and Georgia - Continued

\begin{tabular}{|c|c|}
\hline $\begin{array}{l}\text { Sample } \\
\text { (figs. 2, 3) }\end{array}$ & Locality and Description \\
\hline \multicolumn{2}{|r|}{ Dorchester County, S. C. - Continued } \\
\hline $\begin{array}{r}\text { 48-Mt-66_- }-- \\
67 \_---\end{array}$ & $\begin{array}{l}\text { Ridgeville quadrangle. Same locality as No. } 65 \text {. Sample from semiconsolidated sand that forms the } \\
\text { lower } 4 \mathrm{ft} \text { of an } 8 \text {-ft section. } \\
\text { Ridgeville quadrangle. Northeast side of U.S. Highway } 78 \text {, about } 3.3 \text { miles } \mathrm{S} .72^{\circ} \text { E. of Ridgeville, on } \\
\text { southeast side of Ashley River. Altitude about } 40 \mathrm{ft} \text {, Talbot terrace. Clayey material from a section } \\
4 \mathrm{ft} \text { thick. }\end{array}$ \\
\hline \multicolumn{2}{|r|}{ Georgetown County, S. C. } \\
\hline $\begin{array}{l}73_{----} \\
74_{----}\end{array}$ & $\begin{array}{l}\text { Georgetown North quadrangle. Southeast side of a secondary road, about } 1.62 \text { miles N. } 35^{\circ} \mathrm{W} \text {. from } \\
\text { bend in U.S. Highway } 521 \text {, west of Georgetown; also } 100 \text { yds southwest of junction of secondary } \\
\text { road with Johnson Road. Altitude } 25 \mathrm{ft} \text {, Pamlico terrace. Fine yellow sand from a } 4 \text {-ft section in pit } \\
\text { excavated for road material. } \\
\text { Georgetown North quadrangle. South bank of Black River, about } 8 \text { miles } \mathrm{N} \text {. } 13^{\circ} \mathrm{W} \text {. of Georgetown, } \\
\text { and } 700 \mathrm{ft} \text { west of pumping station. Altitude about } 18 \mathrm{ft} \text {, Pamlico terrace. Yellowish-brown sandy } \\
\text { clay from a } 4 \text {-ft section. } \\
\text { Rhems quadrangle. East side of Browns Ferry Road, about } 1.3 \mathrm{miles} \text { southeast of Browns Ferry. } \\
\text { Altitude } 25-30 \mathrm{ft} \text {, Talbot terrace. Yellow sand from a section } 61 / 2 \mathrm{ft} \text { thick. } \\
\text { Rhems quadrangle. Southwest side of Browns Ferry Road, about } 0.35 \text { mile west-northwest of Browns } \\
\text { Ferry. Altitude about } 20 \mathrm{ft} \text {, dune on shoreline of Pamlico terrace. Fine yellow sand in roadcut, of } \\
\text { which } 4 \mathrm{ft} \text { was sampled. } \\
\text { Rhems quadrangle. Northeast side of Browns Ferry Road, about } 0.1 \text { mile southeast of road junction } \\
\text { at Red Hill. Altitude } 20-30 \mathrm{ft} \text {, Black Mingo Formation. Brownish-red to dark-red, well- } \\
\text { consolidated sandstone and grit that disintegrate when panned. Sample from section } 12 \mathrm{ft} \text { thick. } \\
\text { Olin quadrangle. Northeast side of U.S. Highway } 521 \text { about } 1.63 \text { miles northwest of Oak Grove, and } \\
\text { 0.2 mile northwest of junction with Bethel Road. Altitude } 28 \mathrm{ft} \text {, Talbot terrace. Mottled red and } \\
\text { orange clayey sand at top, and less clayey sand at base, of a section } 4 \mathrm{ft} \text { thick. }\end{array}$ \\
\hline
\end{tabular}

Orangeburg County, S. C.

48-Mt-46_ _ _ - Orangeburg quadrangle. Northwest side South Carolina Highway 33, about a quarter of a mile northeast of Snake Swamp. Altitude $185 \mathrm{ft}$, Coharie terrace. Section of $7 \mathrm{ft}$, of which sample was of

lower $3 \mathrm{ft}$. Fine-grained mottled white to reddish-brown clayey sand.
$47-1$ - - Orangeburg quadrangle. Same locality as No. 46. Sample of upper $4 \mathrm{ft}$ of section. Reddish-brown limonitic sand, more clayey than No. 46.

48_-_- Orangeburg quadrangle. Northwest side State Highway 33, about 1/8 mile southwest of Snake Swamp. Altitude $170 \mathrm{ft}$, Coharie terrace. Section $6 \mathrm{ft}$ thick of quartzose grit with pebbles up to half

an inch in size, exposed in an old excavation. Material mottled from light tan to brown to red.
49_-- Orangeburg quadrangle. Same general locality as No. 48, but from an 8-ft section $40 \mathrm{ft}$ to the north.

$50 \_--$Orangeburg quadrangle. Secondary road leading northwest from State Highway 33 , about 0.2 mile Hazlehurst terrace. Sample from lower $3 \mathrm{ft}$ of sandy material, in a section $6 \mathrm{ft}$ thick.

51__- - Orangeburg quadrangle. North side of Bennecker Bridge Road, and 7.1 miles S. $62^{\circ} \mathrm{W}$. of center of Orangeburg. Altitude $250 \mathrm{ft}$, Hazlehurst terace. Mottled white to brown to red pebbly sand, with quartz pebbles up to half an inch in size. Sample from lower $3 \mathrm{ft}$ of two cuts.

52. _ - Orangeburg quadrangle. South side of State Highway 36 , about 0.45 mile west of Cooper Swamp; and 10.8 miles S. $20^{\circ} \mathrm{W}$. of center of Orangeburg. Altitude $155 \mathrm{ft}$, Sunderland terrace. Sample from 3 -ft cut of quartzose grit, with grains of quartz from very small size to $3 / 8$ inch

53_ _ - Orangeburg quadrangle. North side of State Highway 36, about 0.1 mile west of North Fork of Edisto River, and 9.65 miles S. $11^{1 / 2}{ }^{\circ} \mathrm{W}$. of the center of Orangeburg. Altitude about $150 \mathrm{ft}$, Sunderland terrace. Reddish-brown to yellowish-brown clayey sand, from the lower $6 \mathrm{ft}$ of a 9 -ft section.

58_ _ _ _ Eutawville quadrangle. North side of State Highway 6 , about $7 / 8$ mile west of junction of State Highway 6 with U.S. Highway 15. Altitude $120 \mathrm{ft}$, Okefenokee terrace. Brown unconsolidated to little-consolidated sand, from a section $4 \mathrm{ft}$ thick.

59_-_ - Eutawville quadrangle. South side of State Highway 45, about half a mile west of Eutaw Springs, and 75 yds east of junction of State Highways 45 and 6 . Altitude $100 \mathrm{ft}$, Wicomico terrace. Yellowish-brown unconsolidated sand from a section $6 \mathrm{ft}$ thick.

$60 \ldots$ _ _ - Eutawville quadrangle. South side of State Highway 45, about 21/4 miles west of Eutawville. Altitude $140 \mathrm{ft}$, dune on Wicomico terrace. Yellow sand from a section $2 \mathrm{ft}$-thick.

61_ _ - Bowman quadrangle. North side of State Highway 4, about $1 / 4$ mile west of Four Hole Swamp. Altitude $140 \mathrm{ft}$, Okefenokee terrace. Coherent reddish sandstone, with shite mottling, from an old excavation, in a section $4 \mathrm{ft}$ thick.

Williamsburg County, S. C.

48-Mt- 77_ _ - Andrews quadrangle. Northeast side of U.S. HIghway 521, about 0.6 mile N. $10^{\circ}$ E. of West Andrews. Altitude $35 \mathrm{ft}$, Talbot terrace. Sample from a section $6 \mathrm{ft}$ thick, consisting of $4 \mathrm{ft}$ of yellow clay overlain by $2 \mathrm{ft}$ of leached white sand.

78 _ _ - Indiantown quadrangle. Northeast side of U.S. Highway 521, about 4.8 miles west of Warsaw, and $200 \mathrm{yds}$ east of Spring Gully Church. Altitude $40 \mathrm{ft}$, Talbot terrace. Section of $3 \mathrm{ft}$ of yellowish-

brown clayey sandstone, overlain by $3 \mathrm{ft}$ of dune sand. Sample from lower $3 \mathrm{ft}$ of section.
$79 . \ldots$ - - Indiantown quadrangle. Northeast side of U.S. Highway 521 , about 6.85 miles $\mathrm{N}$. $77^{\circ}$ W. of Warsaw, and 0.4 mile southeast of Spring Gully. Altitude 40 feet, Talbot terrace, close to Talbot shoreline. Reddish-brown slightly sandy clay, from a section $4 \mathrm{ft}$ thick. 
TABLE 1. - Locality and description of samples from the Coastal Plain of South Carolina and Georgia - Continued

Sample

(figs. 2, 3)
Locality and description

\section{Brantley County, Ga.}

48-Mt- 91_ _. _ Nahunta quadrangle. North side of U.S. Highway 84, about 1 1/2 miles east of Waynesville. Altitude about 60 feet, outside bar on Penholoway terrace. Light- to dark-yellow consolidated sand, in section $5 \mathrm{ft}$ thick.

$92 \ldots$ _ _ Nahunta quadrangle. North side of U.S. Highway 84, at crest of hill about 1,2 mile west of Satilla River. Altitude about $70 \mathrm{ft}$, bar or beach on Penholoway terrace. White sand in section $7 \mathrm{ft}$ thick, in pit on north side road.

93_ _ _ N Nahunta quadrangle. North side of U.S. HIghway 84, about 0.7 mile east of Lulaton, and 5.6 miles west of railroad crossing in Nahunta. Altitude about $80 \mathrm{ft}$, Hawthorn Formation (Miocene age), overlain by $3 \mathrm{ft}$ of sand of the Penholoway Formation. Sample of a 7 - $\mathrm{ft}$ section of the Hawthorn Formation.

94 - Winokur quadrangle. South side of U.S. Highway 84, about 1.2 miles east of Hoboken fire tower. Altitude about $70 \mathrm{ft}$, Penholoway shoreline on east side of Trail Ridge. Fairly coarse carbonaceous sand with grains of uniform size, and no clay, from a dug section $5 \mathrm{ft}$ thick.

sand with grains of uniform size, and no clay, from a dug section $5 \mathrm{ft}$ thick.
$95 \ldots$ - Winokur quadrangle. South side of U.S. Highway 84 , about 0.5 mile east of Hoboken fire tower. Altitude about $100 \mathrm{ft}$, shoreline of Wicomico terrace, on east side of Trail Ridge. Coarse carbonaceous sand from section $4 \mathrm{ft}$ thick.

96_ _ - Winokur quadrangle. North side of U.S. Highway 84, about 200 yds east of Hoboken fire tower Altitude about $140 \mathrm{ft}$, shoreline of Okefenokee terrace, on east side of Trail Ridge. Sample of section $8 \mathrm{ft}$ thick. Upper $4 \mathrm{ft}$ consists of unconsolidated gray carbonaceous sand; lower $4 \mathrm{ft}$ is consolidated brown sandstone.

Camden County, Ga.

48-Mt- 97_ _ _ Boulogne quadrangle. South side of Whiteoak-Folkston unpaved road, about $1^{1 / 4}$ miles westsouthwest of Jerusalem. Altitude about $45 \mathrm{ft}$, east side of an abrupt rise at about the level of the Talbot terrace. Hard-packed white sand at base, overlain by carbonaceous sand, and by 12 in. of windblown sand, in section $6 \mathrm{ft}$ thick.

$98 \ldots$ _ - Boulogne quadrangle. North side of Whiteoak-Folkston unpaved road, about 13/8 miles westsouthwest of Jerusalem. Altitude about $65 \mathrm{ft}$, Penholoway terrace. Light-yellow sand overlain by 12 in. of windblown sand in dug section of $6 \mathrm{ft}$.

\section{Charlton County Ga.}

48-Mt- 99 _. _ Boulogne quadrangle. West side of Burnt Fork-Folkston unpaved road, about 3.4 miles S. $71^{\circ} \mathrm{W}$. from Burnt Fork (crossing of Satilla River). Altitude $60 \mathrm{ft}$, Penholoway terrace. Section of $5 \mathrm{ft}$ of white sand that rests on Hawthorn Formation.

$100_{-} \ldots$ - Folkston quadrangle. West side of U.S. Highway 1, on west side of Atlantic Coast Line Railroad and 3.3 miles N. $38^{\circ} \mathrm{W}$. of Uptonville. Altitude about $100 \mathrm{ft}$, Wicomico terace, along east side of Trail

Ridge. Gray sand from upper $6 \mathrm{ft}$ of cut.
$101 \ldots \ldots$ Folkston quadrangle. East side of U.S. Highway 1, at entrance to side road leading to Sand Hill Church, and $6^{1 / 4}$ miles N. $29^{\circ} \mathrm{W}$. of Uptonville. Altitude about $145 \mathrm{ft}$, Okefenokee terrace. Dug section $4 \mathrm{ft}$ thick of yellow sand, overlain by a thin veneer of windblown sand.

Glynn County, Ga.

48-Mt- 89_ _ _ Bladen quadrangle. North side of U.S. Highway 84, about 2.3 miles east of College Creek, and 2.7 miles east of junction with State Highway 99. Altitude not exactly known, probably a bar on Pamlico terrace. Gray sand in roadcut $4^{1 / 2} \mathrm{ft}$ high.

$90 \ldots$ _ _ Nahunta quadrangle. North side of U.S. Highway 84, about 2.6 miles east of Waynesvile, and 2.8 miles west of crossing of Seaboard Railroad. Altitude about $21 \mathrm{ft}$, Pamlico terrace near Pamlico shoreline. Roadcut $3 \frac{1 / 2}{\mathrm{ft}}$ high, of which upper half is light-gray carbonaceous sand; lower half is clayey yellow sand.

The tenors of total heavy minerals in the Pleistocene terraces of South Carolina range from 0.68 to 0.017 weight percent, with a mean value of 0.14 percent. This is about twice as great as the mean tenor for the monazite-bearing crystalline rocks, but is almost exactly that of all the granitic rocks that I sampled in the Southeastern States. On the other hand, the tenors of accessory minerals in the sampled Pleistocene terraces of Georgia range from 0.96 to 0.078 weight percent, with a mean value of 0.36 percent, which is $2 \frac{1}{2} 2$ times greater than in South Carolina. 
TABLE 2.-Accessory minerals from sedimentary rocks

[Tr., trace; _-_, absent. Mineralogy by

\begin{tabular}{|c|c|c|c|c|c|}
\hline \multirow{2}{*}{$\begin{array}{l}\text { Field No. } \\
\text { (figs.2,3) }\end{array}$} & \multicolumn{3}{|c|}{$\begin{array}{c}\text { Heavy minerals in bedrock } \\
\text { (weight percent) }\end{array}$} & \multicolumn{2}{|c|}{$\begin{array}{c}\text { Heavy minerals in } \\
\text { concentrates (weight percent) }\end{array}$} \\
\hline & $\begin{array}{l}\text { Geologic } \\
\text { setting }\end{array}$ & Total & Monazite & Ilmenite & Leucoxene \\
\hline \multicolumn{6}{|c|}{\begin{tabular}{|c|c|c|} 
& Terraces of Pleistocene age \\
\end{tabular}} \\
\hline 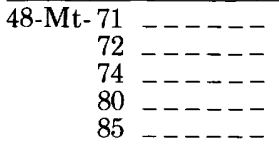 & $\begin{array}{l}\text { Pamlico } \\
--- \text { do }----- \\
--- \text { do }----- \\
--- \text { do }----- \\
--- \text { do }------\end{array}$ & $\begin{array}{l}0.184 \\
.123 \\
.114 \\
.337 \\
.442\end{array}$ & $\begin{array}{c}0.0018 \\
.0025 \\
.0023 \\
.0034 \\
---\end{array}$ & $\begin{array}{l}68 \\
73 \\
74 \\
58 \\
27\end{array}$ & $\begin{array}{l}-\overline{2}- \\
--- \\
\overline{\text { Tr. }}\end{array}$ \\
\hline 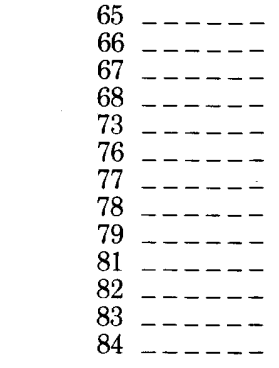 & $\begin{array}{l}\text { Talbot } \\
--- \text { do }------ \\
--- \text { do }------ \\
--- \text { do }------ \\
--- \text { do }------ \\
--- \text { do }------ \\
--- \text { do }----- \\
--- \text { do }----- \\
--- \text { do }----- \\
--- \text { do }------ \\
--- \text { do }----- \\
--- \text { do }------ \\
-- \text { do }------\end{array}$ & $\begin{array}{l}.047 \\
.069 \\
.038 \\
.123 \\
.146 \\
.024 \\
.040 \\
.109 \\
.034 \\
.620 \\
.034 \\
.026 \\
.050\end{array}$ & $\begin{array}{l}.0023 \\
.0014 \\
.0004 \\
.0061 \\
.0015 \\
.0002 \\
.0004 \\
.0022 \\
.0010 \\
---- \\
.0005 \\
.0015\end{array}$ & $\begin{array}{l}60 \\
62 \\
68 \\
50 \\
64 \\
40 \\
65 \\
66 \\
56 \\
62 \\
50 \\
71 \\
67\end{array}$ & $\begin{array}{l}\text { Tr. } \\
\text { Tr. } \\
-\overline{3}- \\
-\frac{-}{2}- \\
3 \\
2 \\
-\frac{3}{3}- \\
-\frac{1}{1}- \\
\text { Tr. }\end{array}$ \\
\hline $\begin{array}{l}63------ \\
64------ \\
69------ \\
86------\end{array}$ & $\begin{array}{c}\text { Penholoway } \\
--- \text { do }------ \\
--- \text { do }------ \\
--- \text { do }------\end{array}$ & $\begin{array}{l}.137 \\
.056 \\
.106 \\
.075\end{array}$ & $\begin{array}{l}.0027 \\
-\overline{0}-\overline{1} \\
.0022\end{array}$ & $\begin{array}{l}64 \\
45 \\
67 \\
61\end{array}$ & $\begin{array}{l}3 \\
\operatorname{Tr} . \\
\operatorname{Tr} \\
---\end{array}$ \\
\hline $\begin{array}{l}88------ \\
59----- \\
60----- \\
62----- \\
70------\end{array}$ & $\begin{array}{c}\text { Wicomico } \\
--- \text { do }------ \\
--- \text { do }------ \\
--- \text { do }------ \\
--- \text { do }------\end{array}$ & $\begin{array}{l}.676 \\
.049 \\
.024 \\
.189 \\
.236\end{array}$ & $\begin{array}{l}.0135 \\
.0020 \\
.0005 \\
.0057 \\
.0330\end{array}$ & $\begin{array}{l}71 \\
39 \\
29 \\
47 \\
30\end{array}$ & $\begin{array}{l}--- \\
--- \\
\bar{T} \bar{r}- \\
---\end{array}$ \\
\hline $\begin{array}{l}58------ \\
61-----\end{array}$ & $\begin{array}{c}\text { Okefenokee } \\
-- \text { do }-----\end{array}$ & $\begin{array}{l}.017 \\
.131\end{array}$ &.$\overline{0} \overline{13}$ & $\begin{array}{l}31 \\
47\end{array}$ & $\overline{\mathrm{T}} \overline{\mathbf{r}}$. \\
\hline $\begin{array}{l}52------ \\
53------ \\
57------\end{array}$ & $\begin{array}{c}\text { Sunderland } \\
--- \text { do }------ \\
--- \text { do }------\end{array}$ & $\begin{array}{l}.071 \\
.028 \\
.078\end{array}$ & $\begin{array}{l}.0037 \\
.0014 \\
.0031\end{array}$ & $\begin{array}{l}73 \\
37 \\
54\end{array}$ & $\begin{array}{l}--- \\
--- \\
---\end{array}$ \\
\hline $\begin{array}{l}46------ \\
47------ \\
48------ \\
49------ \\
56------\end{array}$ & $\begin{array}{c}\text { Coharie } \\
--- \text { do }----- \\
--- \text { do }------ \\
--- \text { do }------ \\
--- \text { do }------\end{array}$ & $\begin{array}{l}.042 \\
.039 \\
.166 \\
.562 \\
.311\end{array}$ & $\begin{array}{l}.0004 \\
.0027 \\
.0066 \\
.0169 \\
.0093\end{array}$ & $\begin{array}{l}35 \\
25 \\
30 \\
14 \\
46\end{array}$ & $\begin{array}{c}3 \\
3 \\
3 \\
15 \\
---\end{array}$ \\
\hline $\begin{array}{l}50------ \\
51-----\end{array}$ & $\begin{array}{c}\text { Hazlehurst } \\
-- \text { do }-----\end{array}$ & $\begin{array}{l}.085 \\
.024\end{array}$ & $\begin{array}{l}.0059 \\
.0005\end{array}$ & $\begin{array}{l}47 \\
42\end{array}$ & $\begin{array}{l}--- \\
---\end{array}$ \\
\hline Mean ---- & & 0.145 & 0.0036 & 52 & 1 \\
\hline \multicolumn{6}{|c|}{ Tertiary formations } \\
\hline $\begin{aligned} 48-\mathrm{Mt}-54 & ------ \\
55 & ------\end{aligned}$ & $\begin{array}{c}\text { McBean } \\
--- \text { do }------\end{array}$ & $\begin{array}{r}0.019 \\
.033\end{array}$ & $\begin{array}{r}0.0017 \\
.0026\end{array}$ & $\begin{array}{l}39 \\
58\end{array}$ & $\begin{array}{l}--- \\
---\end{array}$ \\
\hline $\begin{array}{l}75------ \\
87------\end{array}$ & $\begin{array}{c}\text { Black Mingo } \\
-- \text { do }-----\end{array}$ & $\begin{array}{l}.276 \\
.081\end{array}$ & $\begin{array}{l}.0028 \\
.0016\end{array}$ & $\begin{array}{l}56 \\
70\end{array}$ & Tr. \\
\hline Mean ---- & & 0.102 & 0.0022 & 56 & --- \\
\hline
\end{tabular}


in eight counties. Coastal Plain of South Carolina

Eleanor Thompson and Judith Weiss Frondel]

\begin{tabular}{|c|c|c|c|c|c|c|}
\hline \multicolumn{7}{|c|}{$\begin{array}{l}\text { Heavy minerals in } \\
\text { concentrates (weight percent) }\end{array}$} \\
\hline Monazite & Epidote & Garnet & Staurolite & Zircon & Rutile & $\begin{array}{l}\text { Quartz and } \\
\text { others }\end{array}$ \\
\hline \multicolumn{7}{|c|}{ Terraces of Pleistocene age - Continued } \\
\hline 1 & --- & Tr. & 6 & 21 & 4 & Tr. \\
\hline 2 & $-\ldots$ & $\ldots$ & 4 & 11 & 4 & 4 \\
\hline$\overline{2}$ & - - & Tr. & 2 & 19 & 3 & Tr. \\
\hline$\overline{1}$ & 10 & Tr. & 2 & 25 & 3 & 1 \\
\hline Tr. & 14 & -- & 1 & 4 & Tr. & 54 \\
\hline 5 & 1 & - - & 3 & 21 & 3 & 7 \\
\hline 2 & 1 & --- & 2 & 17 & 6 & 10 \\
\hline 1 & $\ldots$ & -- & 2 & 18 & 4 & 7 \\
\hline 5 & --- & $-\ldots$ & Tr. & 35 & 5 & 2 \\
\hline 1 & 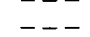 & Tr. & 2 & 28 & 5 & Tr. \\
\hline 1 & --- & $\ldots$ & Tr. & 14 & 2 & 41 \\
\hline 1 & $\overline{2}$ & --- & 5 & 11 & 5 & 8 \\
\hline 2 & 2 & $-\ldots$ & 2 & 16 & 6 & 4 \\
\hline 3 & 4 & -- & $\overline{1}$ & 25 & 3 & 8 \\
\hline$\ldots$ & 8 & -- & 6 & 11 & 6 & 4 \\
\hline-- & 5 & -- & 1 & 22 & 5 & 17 \\
\hline 2 & 4 & -- & 1 & 14 & 2 & 5 \\
\hline 3 & --- & --- & Tr. & 16 & 3 & 11 \\
\hline 2 & --- & --- & 4 & 16 & 6 & 5 \\
\hline $\operatorname{Tr}$ & 4 & -- & 7 & 24 & 8 & 12 \\
\hline 2 & --- & --- & 4 & 15 & 3 & 9 \\
\hline 3 & --- & --- & 1 & 30 & 5 & Tr. \\
\hline 2 & 3 & - - - & 1 & 11 & 3 & 9 \\
\hline 4 & --- & --- & Tr. & 17 & 9 & 31 \\
\hline 2 & 3 & -- & -- & 43 & 10 & 13 \\
\hline 3 & 1 & & 5 & 16 & 7 & 21 \\
\hline 14 & 6 & Tr. & Tr. & 6 & 1 & 43 \\
\hline Tr. & 2 & --- & 5 & 34 & 12 & 16 \\
\hline 1 & 2 & --- & 6 & 7 & 7 & 30 \\
\hline 5 & 2 & --- & $\operatorname{Tr}$. & 14 & 2 & 4 \\
\hline 5 & $\overline{1}$ & --- & 3 & 26 & 9 & 19 \\
\hline 4 & -- & -- & Tr. & 13 & 3 & 26 \\
\hline 1 & 3 & --- & 2 & 6 & 3 & 47 \\
\hline 7 & 3 & -- & 3 & 26 & 9 & 24 \\
\hline 4 & 7 & -- & 5 & 10 & 7 & 34 \\
\hline 3 & 4 & - - - & 3 & 6 & 6 & 49 \\
\hline 3 & Tr. & --- & 2 & 41 & 7 & 1 \\
\hline 7 & --- & -- & Tr. & 6 & 3 & 37 \\
\hline 2 & --- & -- & 8 & 7 & 10 & 31 \\
\hline 3 & 2 & --- & 3 & 18 & 5 & 16 \\
\hline \multicolumn{7}{|c|}{ Tertiary formations - Continued } \\
\hline 9 & Tr. & $-\ldots$ & - - - & 8 & 4 & 40 \\
\hline 8 & Tr. & --- & -- & 15 & 5 & 14 \\
\hline 1 & 3 & - - - & 2 & 20 & 3 & 15 \\
\hline 2 & --- & --- & 1 & 24 & 3 & Tr. \\
\hline 5 & 1 & --- & 1 & 16 & 4 & 17 \\
\hline
\end{tabular}


T ABLE 3. - Accessory minerals from sedimentary rocks

[Tr., trace; _- - , absent. Mineralogy by

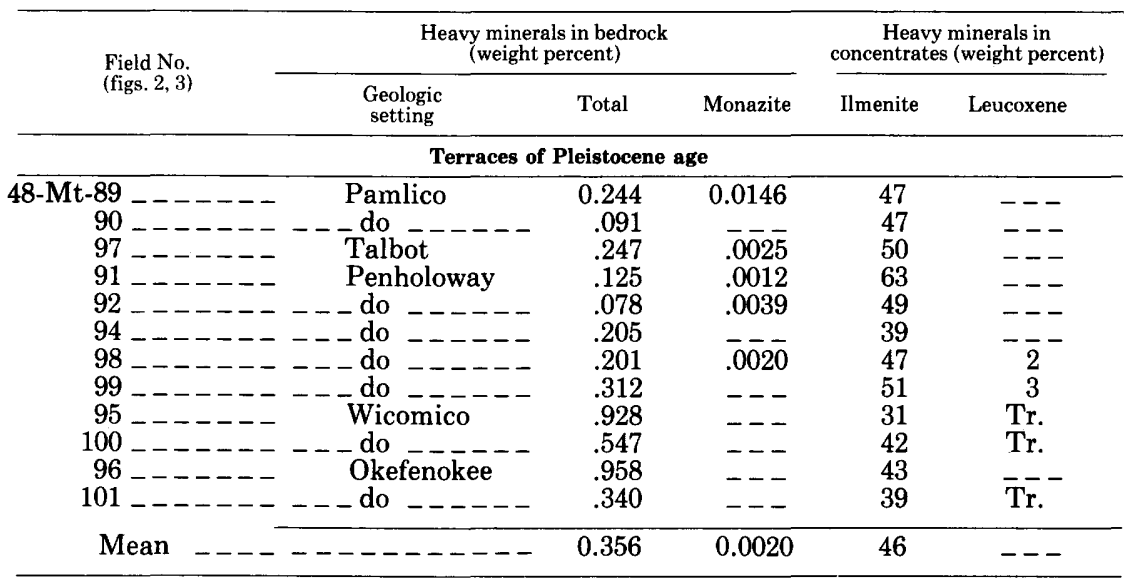

Miocene sedimentary rock

\begin{tabular}{llllll}
\hline 48-Mt-93 _- - - - & $\begin{array}{l}\text { Hawthorn } \\
\text { Formation }\end{array}$ & 0.077 & 0.0062 & 67 & ---
\end{tabular}

Too few samples of the Tertiary formations were taken to warrant any dependable conclusions, but the tenor of total accessory minerals appears to be lower. The tenor of accessory minerals in the Upper Cretaceous Tuscaloosa Formation, where it overlaps the crystalline rocks, is probably greater than in any of the Tertiary formations.

Magnetite is absent in all these Coastal Plain formations. Ilmenite is everywhere present, but is twice as plentiful in the Pleistocene terraces sampled in Georgia than in those sampled in South Carolina, thus partly accounting for the greater volume of accessory minerals in Georgia. Small amounts of leucoxene are recorded in both sets of samples, thus indicating losses in the total amounts of ilmenite. Much of the ilmenite may have been altered to leucoxene after the hostsediments were deposited, and thus the leucoxene may be mainly a product of alteration by ground water.

The monazite, zircon, and rutile contents are likewise two to five times greater in the samples from Georgia than in those from South Carolina. This might be interpreted to mean that the heavy mineral content of the Pleistocene terraces increases southwestward from the Carolinas; alternatively, the areas in Georgia might be more favorably situated for the accumulation of heavy minerals than those in South Carolina. Much surficial and underground exploration, as well as a better knowledge of the terraces and of their formation, will be required to settle this and related questions.

Insufficient data are at hand to determine whether the content of 
in four counties, Coastal Plain of Georgia

Eleanor Thompson and Judith Weiss Frondel]

\begin{tabular}{|c|c|c|c|c|c|c|}
\hline \multicolumn{7}{|c|}{$\begin{array}{l}\text { Heavy minerals in } \\
\text { concentrates (weight percent) - Continued }\end{array}$} \\
\hline Monazite & Epidote & Garnet. & Staurolite & Zircon & Rutile & $\begin{array}{l}\text { Quartz and } \\
\text { others }\end{array}$ \\
\hline \multicolumn{7}{|c|}{ Terraces of Pleistocene age - Continued } \\
\hline 6 & --- & --- & 2 & 38 & 7 & Tr. \\
\hline--- & --- & $\overline{\mathrm{T}} \mathbf{r}$ & 4 & 40 & 8 & 1 \\
\hline$-\overline{1}$ & $\begin{array}{l}--- \\
---\end{array}$ & -- & 4 & 38 & 5 & 2 \\
\hline 1 & --- & --- & 2 & 27 & 7 & Tr. \\
\hline 5 & $\begin{array}{l}--- \\
---\end{array}$ & $\begin{array}{l}--- \\
---\end{array}$ & 2 & 38 & 6 & Tr. \\
\hline $\operatorname{Tr}$ & $--\overline{5}$ & $\begin{array}{l}--- \\
---\end{array}$ & 4 & 28 & 6 & 18 \\
\hline 1 & & $\overline{\mathrm{T}} \mathbf{r}$ & 2 & 27 & 9 & 12 \\
\hline $\operatorname{Tr}$ & $--\overline{5}$ & --- & 2 & 27 & 8 & 4 \\
\hline $\operatorname{Tr}$ & 1 & --- & 3 & 24 & 4 & 37 \\
\hline--- & 4 & --- & 4 & 29 & 7 & 14 \\
\hline--- & 2 & --- & 4 & 27 & 4 & 20 \\
\hline--- & 2 & $\operatorname{Tr}$ & 1 & 50 & 7 & 1 \\
\hline 1 & 2 & --- & 3 & 33 & 6 & 9 \\
\hline \multicolumn{7}{|c|}{ Miocene sedimentary rock - Continued } \\
\hline 8 & Tr. & --- & 2 & 18 & 5 & Tr. \\
\hline
\end{tabular}

accessory minerals increases or decreases with age in the Pleistocene terraces. High-grade samples occur in the interval 20-230 feet above sea level in the Pamlico, Talbot, Wicomico, and Coharie terraces, and so workable deposits are likely to be found in terraces within this range of altitudes. High contents of heavy minerals were noted in terraces at similar altitudes during prospecting and mining in Florida.

Part of the concentration of the accessory minerals is due to the destruction and elimination by chemical and mechanical means of certain essential minerals of the granitic rocks in the Piedmont. Feldspars, the most vulnerable of such minerals, constitute about 60 percent of most granitic rocks. These and other vulnerable minerals may comprise 75 percent of the country rock, and their elimination could cause a fourfold increase in the accessory minerals. On the other hand, the partial destruction of iron ores as a result of erosional processes will cause a decrease in the accessory mineral content, and processes of mechanical concentration associated with fluvial transport and winnowing have upgraded the relative abundances of the heavy minerals. The accessory minerals of the crystalline rocks have been concentrated from 10- to 25fold in the sedimentary rocks of the Coastal Plain.

Magnetite is not found in accessory minerals of the Coastal Plain, although it is common in the crystalline rocks. If this mineral had survived chemical alteration, erosion, and fluvial transportation, the total iron ores in the Coastal Plain formations would have been much greater, and in the Pleistocene terraces of Georgia the mean tenor of 
TABLE 4. - Comparative mean tenors, in weight percent, of accessory minerals in crystalline rocks and Pleistocene terraces

\begin{tabular}{|c|c|c|c|}
\hline \multirow{2}{*}{ Accessory minerals } & \multirow{2}{*}{ Crystalline rocks } & \multicolumn{2}{|c|}{ Pleistocene terraces } \\
\hline & & South Carolina & Georgia \\
\hline $\begin{array}{l}\text { Total accessory minerals } \\
\text { Magnetite } \\
\text { Ilmenite } \\
\text { Monazite } \\
\text { Zircon }---- \\
\text { Rutile }\end{array}$ & $\begin{array}{l}0.072 \\
.017 \\
.029 \\
.0047 \\
.0022 \\
.0008\end{array}$ & $\begin{array}{l}0.14 \\
\text { Absent } \\
.073 \\
.0036 \\
.022 \\
.0070\end{array}$ & $\begin{array}{l}0.36 \\
\text { Absent } \\
.15 \\
.0020 \\
.11 \\
.022\end{array}$ \\
\hline
\end{tabular}

iron ores might have been 0.25 percent rather than 0.15 percent. The potential concentration of iron ores, from hardrock to the sands of the Coastal Plain, is on the order of 1:5.

The tenor of monazite in the Pleistocene terraces is less than in the monazite-bearing crystalline rocks of the monazite belts (fig.1). This apparent anomaly results from the Pleistocene sands being derived from crystalline rocks, both within and without the monazite belts. Considerable concentration of monazite is indicated by the tenor of monazite in the terraces approaching that in the crystalline rocks, even though the monazite-free rocks greatly exceed in volume those that contain monazite. Zircon and rutile, the most durable of the accessory minerals, show maximum concentrations, respectively, of $1: 50$ and $1: 27$.

These data have a bearing upon the origin of the Coastal Plain formations. The concentration of accessory minerals, though striking, is much less than might be expected of beach deposits; and clearly the mean tenor of accessory minerals in the samples from Georgia is only a tenth of that in the commercial deposits of Florida. Beach deposits have been formed continuously since the Late Cretaceous; yet most of the deposits now exposed are not marine deposits. Judging by the concentration of accessory minerals on the beaches of the inland waterways of the Coastal Plain, such as Indian River, Fla., the deposits are not dominantly estuarine. Therefore, the beach deposits must be buried, and the visible formations must be interpreted as outwash or deltaic deposits that were subjected to repeated fluvial concentration by wandering and migrating rivers and streams. The formation of these deposits and the concentration of their heavy minerals, however, had to be of such a nature as to winnow most of the clay, inasmuch as these deposits, though locally clayey, are mainly sands. This inference suggests that the deposits now visible may have originated in the headwater stretches of deltaic areas, rather than farther downstream close to the ocean. 


\section{PLACER MINING}

Placer mining in the Coastal Plain is mainly for ilmenite; monazite is a small, local byproduct. At one site in South Carolina, however, monazite was the main mineral produced. This was the Horse Creek deposit in Aiken County.

\section{SOUTH CAROLINA}

A fluvial placer of heavy minerals was discovered during the summer of 1951 by Owen H. Perry in the lower valley of Horse Creek in Aiken County, S.C. A similar placer of lower grade exists in the valley of Hollow (Holley) Creek, southeast of Horse Creek (Overstreet, 1967, p. 259-260). Horse Creek heads in Edgefield County and flows in a general southwesterly direction to join the Savannah River at a point southwest of Aiken. A part of the placer on Horse Creek was drilled by the U.S. Bureau of Mines in the winter of 1951-52 (Kline and others, 1954). Thereafter, Perry transported to Horse Creek and reassembled there a 6-foot bucket dredge which he had used from 1939 to 1944 for gold and sapphire mining on Eldorado Bar, Missouri River, northwest of Canyon Ferry, Mont. This dredge, as it appeared in April 1956 in the valley floor of Horse Creek, is pictured in figure 4. This property and equipment were controlled at first by Perry, with the financial backing of the Callahan Lead and Zinc Co. Later, ownership passed to the Crane Co., and still later the property came to be owned by the Vitro Corporation of America, and the French Pechiney organization. This property, though otherwise named at the outset of mining, came finally to be known as the Heavy Minerals Co. Dredging began about a mile from the Savannah River, on the northwest side of the Southern Railway, and was extended upstream. Later the dredge was moved southeast of the railroad tracks. Mining began in the spring of 1955 (Lenhart, 1956) and was terminated early in 1959 .

This deposit is both underlain and surrounded by the Tuscaloosa Formation of Late Cretaceous age. This formation directly overlaps the crystalline rocks of the Piedmont province, and along its old shoreline the Tuscaloosa might be expected to have a higher tenor in heavy minerals than other formations of the Coastal Plain lying between the Fall Line and the ocean. At favored localities, the Tuscaloosa Formation may even contain workable deposits of heavy minerals, though none as yet has been found. The alluvial placers on Horse and Hollow (Holley) Creeks were formed by the reconcentration of heavy minerals from high-grade parts of the Tuscaloosa Formation. Such alluvial deposits are unlikely to form in large stream valleys that head far west or northwest of the Fall Line, inasmuch as the volume of barren alluvium would be too great to form a workable placer. Small streams 


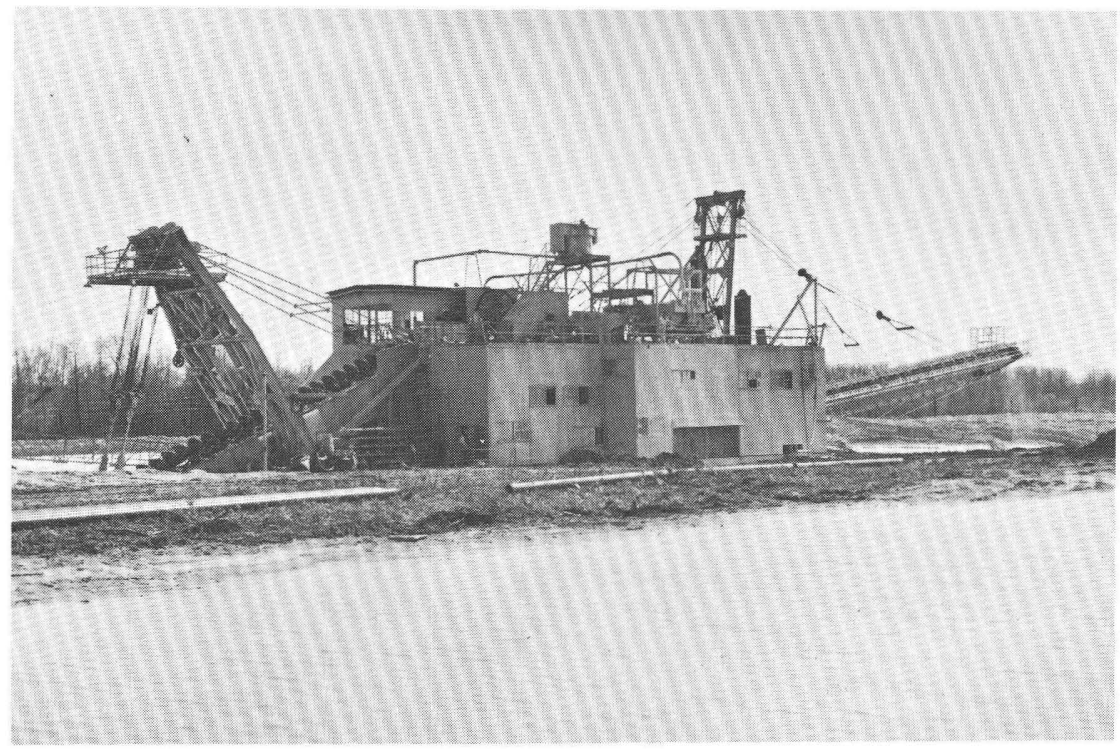

FIGURE 4. - The Perry bucket dredge, operating in the valley floor of Horse Creek, Aiken County, S.C.

that head within the Tuscaloosa Formation, or at no great distance above the Fall Line, are the best sites for prospecting. I found monazite and other heavy minerals in 1951 on a small branch of Sweetwater Creek, about 3 miles east of Thomson, McDuffie County, Ga. The tenor of the gravels in monazite at this locality, as gaged by panning, was estimated to be about half a pound to the cubic yard. Northwest of this locality, monazite was found in the Tuscaloosa Formation at four sites along a road that leads east-northeast from Thomson. As these localities are along the divide between Sweetwater Creek and Sills Branch of Germany Creek, the monazite was close to its bedrock source. A somewhat similar occurrence of monazite was also found in 1951 on Rocky Creek, about 5 miles west-northwest of Lexington, Lexington County, S.C., but the bedrock source of this deposit was not so clearly established.

Thus, possible workable placers can be found by panning, both in the Tuscaloosa Formation and in some of the small streams that drain southeastward from it. Another example, reported by Henry S. Johnson, Jr. (oral commun., 1958), is where the Strategic Minerals Corp. located a deposit near McTier Creek, a south-flowing tributary of the South Fork of the Edisto River, in the northern part of Aiken County, S.C. There 1-3 feet of sand and gravel at the base of the Tuscaloosa Formation, where it overlaps a thoroughly weathered granite, contains about 1 percent heavy minerals that yield as much as 33 percent monazite. To a depth of 60 feet, this deposit covers an area of several 
hundred acres. The underlying granite has not been panned, but the coarseness of the grains of monazite in the sand and gravel suggests that this granite is the bedrock source. If this is so, then this locality is part of the eastern Piedmont monazite belt (fig. 1).

The paystreak on Horse Creek was originally reported to extend from the Savannah River upstream for 7-8 miles, but the subsequent mining impugns this estimate. The width of the paystreak, where the dredge started, was reported to be about 1,800 feet, but its width at the upper end of the minable ground was said to narrow to 800 feet or less. The alluvium, at the initial site of mining, was about 20 feet thick and consisted of silt, sand, and gravel. At the base of the section a stratum of fine quartz gravel about 4 feet thick rests upon a bedrock of the Tuscaloosa Formation. This gravel was sold for use as concrete aggregate.

The Horse Creek deposit probably could not have been mined without its significant content of gravel. The heavy mineral content is believed to be 1-2 percent or, more likely, 1-1.5 percent. The proportions of minerals recovered from the jigs are estimated to be 23 percent ilmenite, 19 percent zircon, 15 percent rutile, 8 percent monazite and xenotime, 7 percent staurolite, and 28 percent quartz and other minerals. The ratio of xenotime to monazite has been variously reported from 1:12 to $1: 32$, but the most probable value is between 1:15 and 1:20. From these data, monazite and xenotime might be inferred to have constituted about 12 percent of the salable minerals.

\section{FLORIDA}

Monazite is present in nearly all samples of heavy minerals recovered in panning or mining the placer deposits of Florida, but the grade is exceedingly low. Nevertheless, in large-scale mining operations where $10,000-25,000$ tons of sand is processed daily, a significant production can be attained. Placer mining of heavy minerals has so far been confined to alluvial deposits along or close to the eastern coast of Florida, and monazite occurs in such ores in amounts ranging from 0.7 to 0.01 percent of the concentrates. The workable deposits have minimum tenors of 3-4 percent in heavy minerals, and so the tenor of monazite in the workable alluvium has the general magnitude of 0.03-0.0003 percent. Despite this low tenor, at two of the three properties where ilmenite, rutile, and zircon were being mined in 1957, a small byproduct of monzite was recovered. At the third plant, the tenor of monazite in the concentrates is considered to be too low to warrant its recovery.

The principal placer mining plants of Florida where ilmenite, rutile, and zircon were being recovered in 1957 had the following ownerships. The National Lead Co. owned a plant operated by the Humphreys Gold Corp. in Duval County, about $2^{3 / 4}$ miles S. $80^{\circ}$ E. of Arlington. The E. 
I. duPont de Nemours and Co. owned and operated two plants, one in Clay County about 5 miles east of Starke, and the other about 7 miles to the north in Bradford County, about three-fourths mile north-northeast of Lawtey. The Hobart Brothers Welding Co. have a plant in Indian River County, mear Wabasso. Other deposits of heavy minerals have been mined, of which the most important was that of the Riz Mineral Co. in Indian River County, about half a mile south of Vero Beach. Small discontinuous deposits of heavy minerals were also worked during World War I in St. Johns County from Mineral City (Ponte Vedra) southward for 17 miles, and in Duval County, north of Mineral City. Similar deposits were mined from 1939 to 1943 for 28 miles along the west shore of Indian River, in Brevard and Indian River Counties. Littoral deposits were mined in 1952-53 along the Atlantic beach in Brevard County, 8-10 miles south of Melbourne. Monazite was identified in all these ores, and it was recovered from some of them (Calver, 1957, p. 15-21).

The principal part of the deposit owned by the National Lead Co. lies north of Atlantic Boulevard, a highway that connects South Jacksonville with the Atlantic beaches; but an extension of this ore body that was being worked in 1957 lies south of the boulevard. The northern, or principal, deposit of mineral-bearing sand had a general subelliptic shape, with maximum dimensions of 1 by 4 miles, trending N. $35^{\circ}$ E.; but the actual area of 900 acres mined from 1943 to 1956 was indefinite in size and shape, depending upon the grade. When mining began, the tenor of heavy minerals to a minimum depth of 12 feet was about 8 percent; but with greater depth the average tenor decreased to about 4 percent. Before mining is finished the grade may decrease to 3 percent, which is regarded as the lower limit of profitable mining for sands of this mineralogical character. Since mining began in 1943, 3,000-10,000 tons of sand has been processed daily; the larger figure was the capacity in 1957.

Mining was started with a dragline excavator, but this was soon replaced by a suction dredge. The heavy minerals are concentrated by a large battery of Humphrey spirals that produce a concentrate consisting of 95 percent heavy minerals. A kiln-dried product then goes to electrostatic separators where ilmenite and rutile are recovered; ilmenite is separated from rutile in other electromagnetic machines. The reject from the first battery of electrostatic separators goes to another battery of Humphrey spirals, where zircon and monzite are separated from most of the minerals of lower density. Monazite is magnetically separated from zircon. The process is much more complex than this brief sketch indicates, as middlings have to be rerun repeatedly in the spirals, the electrostatic separators, and the electromagnetic separators. The suction dredge and a part of the Humphrey spirals are illustrated in figures 5 and 6. 


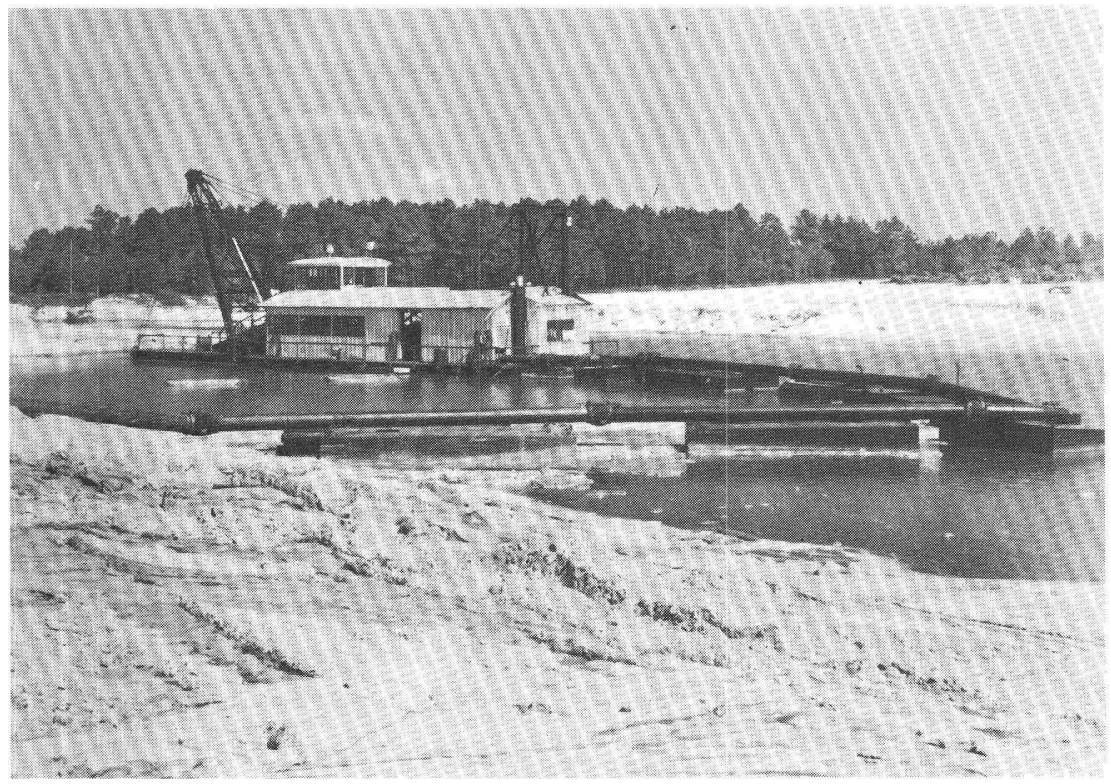

FIGURE 5. - Suction dredge of the National Lead Co., Duval County, Fla.

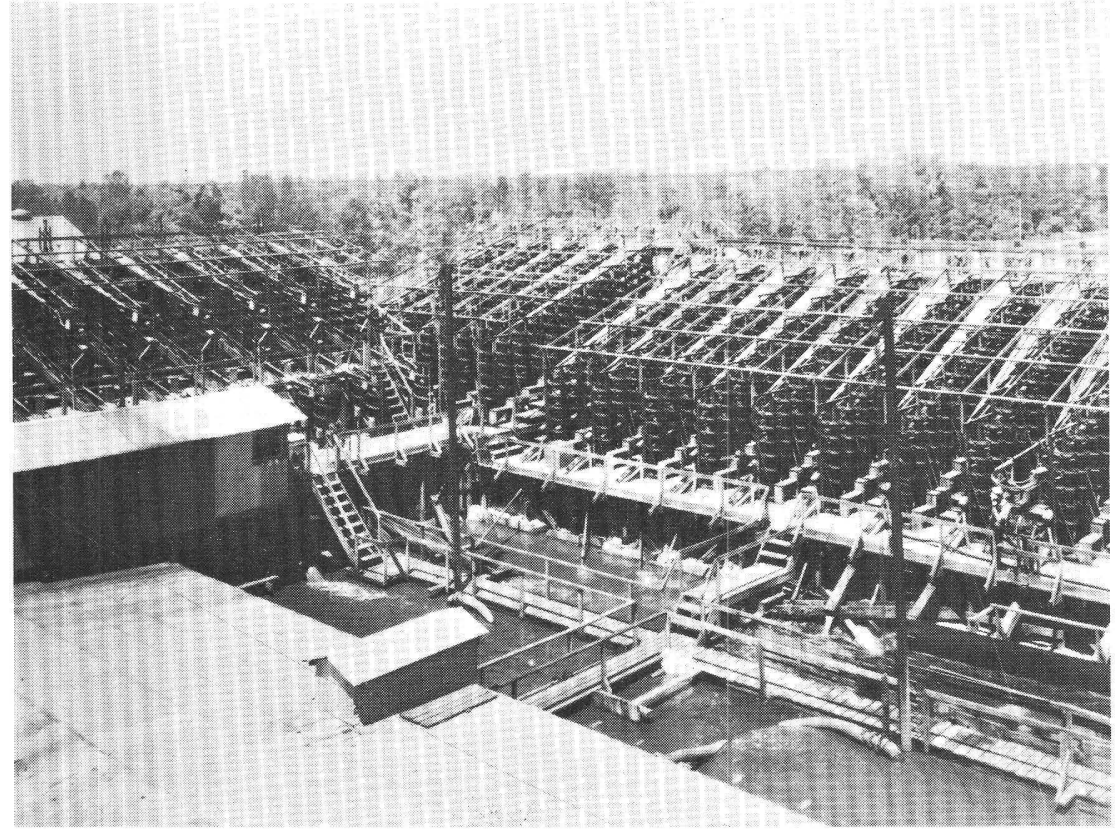

FIGURE 6. - Battery of Humphrey spirals at the plant of the National Lead Co., Duval County, Fla. 
Another ore body owned by the National Lead Co., known as the Skinner tract, which had not been worked as of 1957, lies about $21 \frac{1}{2}$ miles south of the principal ore body. It has a length of about 3 miles, a width of about half a mile, and a workable thickness of 8-10 feet. The mineral-bearing sand, however, does not begin at the surface, but instead lies beneath 20-30 feet of low-grade sand. The workable stratum has a tenor of $4-5$ percent heavy minerals.

The altitude of the northern or principal ore body ranges from 40 to 65 feet and averages 54 feet. The sands that were mined up to 1957 extend from the surface to a depth of 20-30 feet; hence, by reason of altitude, the ore body appears to belong in the Penholoway terrace. But the ore sands show evidence of eolian action, and therefore possibly a part of this deposit is a dune that lies atop the Talbot terrace. The altitude of the top of the ore sand at the Skinner tract ranges from 25 to 35 feet; therefore, this deposit is probably a part of the Talbot terrace, which is covered by dine sand.

The principal ore minerals in the northern ore body are ilmenite, rutile, and zircon, which occur in a variable mean ratio of $4: 1: 1.5$, respectively; but the concentrates also include staurolite, kyanite, sillimanite, tourmaline, monazite, garnet, epidote, and other minerals. The recovery of the principal ore minerals is at least 85 percent. Monazite makes up about 0.7 percent of the concentrates, or about 0.025 percent of the workable sand. Monazite is produced as a small but significant byproduct. Xenotime has not been reported, but this mineral may be rejected with others that are more electromagnetic than monazite, such as staurolite, epidote, and garnet. A small amount of xenotime may remain in the monazite product, because a weak double absorption band in the blue-green that characterizes samarium was noted when this product was examined with the hand spectroscope.

The sizes of the minerals in the concentrates recovered at this plant, as reported by the owners, are listed in table 5 .

The sizes of the grains of monazite, as determined by me, are shown in table 6.

TABLE 5. - Sizes of minerals in concentrates from the northern ore body, National Lead Co. placer, Duval County, Fla.

\begin{tabular}{|c|c|c|c|}
\hline \multicolumn{2}{|r|}{ Grain size } & \multirow{2}{*}{ Material } & \multirow{2}{*}{ Percent } \\
\hline Tyler standard mesh & Millimetres & & \\
\hline $\begin{array}{l}\quad+40 \\
-40 \text { to }+60 \\
-60 \text { to }+80 \\
-80 \text { to }+100 \\
-100 \text { to }+120 \\
-120 \text { to }+140 \\
-140 \text { to }+160 \\
-160 \text { to }+200 \\
-200\end{array}$ & $\begin{array}{l} \\
-0.38 \text { to }+0.38 \\
-0.22 \text { to }+0.17 \\
-0.17 \text { to }+0.15 \\
-0.15 \text { to }+0.12 \\
-0.12 \text { to }+0.11 \\
-0.11 \text { to }+0.096 \\
-0.096 \text { to }+0.074 \\
-0.074 \quad-----\end{array}$ & 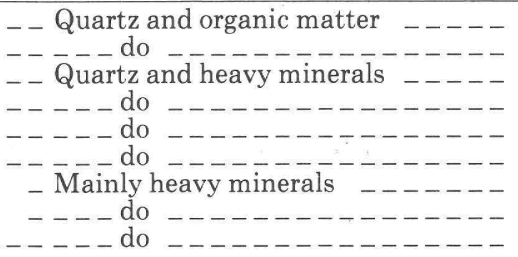 & $\begin{array}{r}0.1 \\
1.3 \\
37.7 \\
41.1 \\
14.6 \\
1.6 \\
1.8 \\
1.2 \\
0.6\end{array}$ \\
\hline
\end{tabular}


TABLE 6. - Sizes of monazite grains from the northern ore body, National Lead Co. placer, Duval County, Fla.

\begin{tabular}{ccr}
\hline \multicolumn{2}{c}{ Grain size } & \multirow{2}{*}{ Percent } \\
\hline Tyler standard mesh & Millimetres & \\
\hline-100 to +140 & -0.15 to $+0.11----------$ & 4.5 \\
-140 to +200 & -0.11 to $+0.074---------$ & 72.0 \\
-200 to +250 & -0.074 to $+0.061---------$ & 15.0 \\
-250 to +325 & -0.061 to $+0.043---------$ & 7.0 \\
-325 & $-0.043-------------$ & 1.5 \\
\hline
\end{tabular}

The two plants operated in 1957 by the E. I. duPont de Nemours and Co. are located on Trail Ridge, which extends from east-central Florida northward into southeastern Georgia. Mining began at the southern plant in 1949 and at the northern plant in 1955 . The mining methods at these two plants are generally similar to those employed by the National Lead Co., with the exception of changes required by local conditions. Much of the ore sand, for example, is so well indurated that it has to be blasted, and thereafter comminuted by a "root hog" underwater macerator, which also cuts up buried stumps. A second difference is that the ore minerals are covered by a carbonaceous coating, which changes their densities and electrical properties. At the outset a scrubbing operation to remove this coating was made a part of the flow sheet, but this was later abandoned, partly on account of the extra expense, and partly because it tended to comminute brittle ore minerals, such as ilmenite. The carbonaceous layer is now removed, though not so completely, by leaching it with a caustic compound. A third difference in mining practice at the southern duPont plant is that the entire assembly of Humphrey spirals is housed on a barge (figs. 7, $8)$.

In 1957 each of these two plants was producing far more total heavy minerals than all other plants in Florida. Monazite, however, was not recovered.

The paystreak at Trail Ridge has a width ranging from 0.5 to 1.5 miles. The ore, which begins at a depth of 5-10 feet below the surface of the ground, extends downward 10-65 feet and has an average thickness of about 35 feet. The U.S. Bureau of Mines (Spencer, 1948) traced this ore body by drilling from a point 2 miles north of Highland in Clay County to the vicinity of Blue Pond Lake on the Camp Blanding Military Reservation, a distance of 19 miles. The mineralogical analysis of 1,622 samples taken from 243 drill holes showed an average grade of 3.9 percent heavy minerals. These results agreed closely with those obtained by the E. I. duPont de Nemours and Co. The actual recovery of heavy minerals is reported to be about 75 percent of this average grade.

The paystreak has not yet been completely outlined. The U.S. Bureau of Mines in 1948 carried out another scout drilling program 


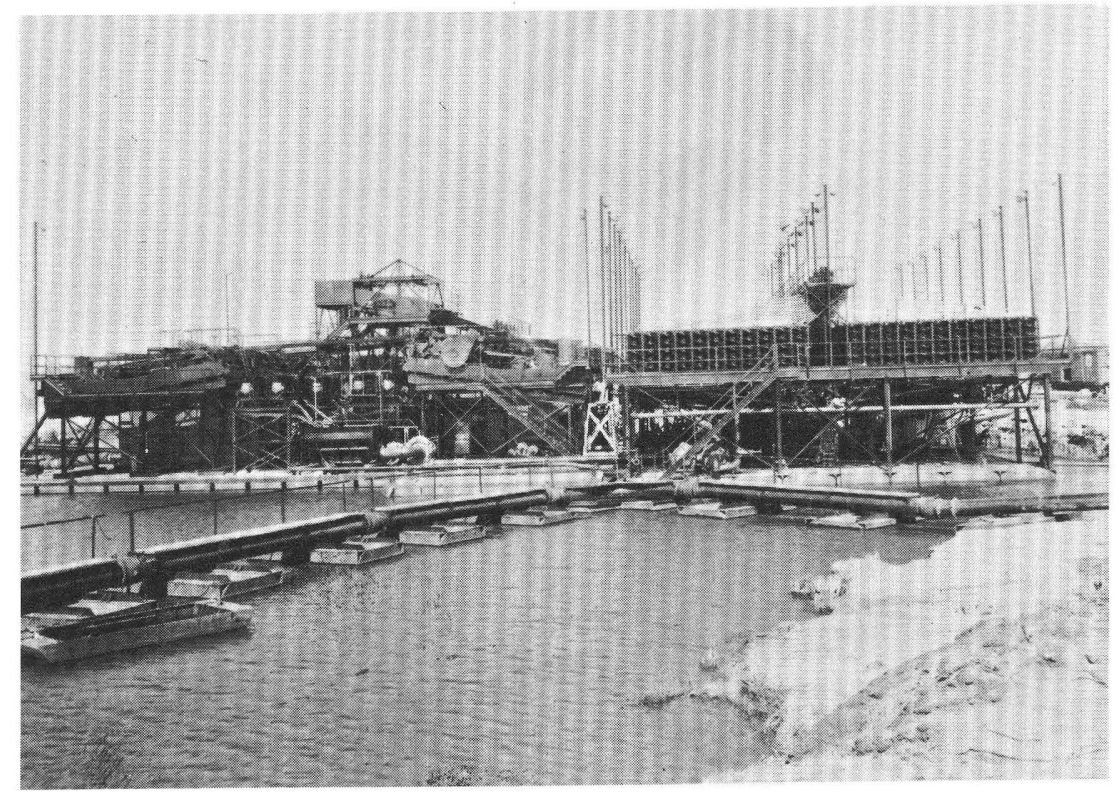

FIGURE 7. - Concentrating plant of Humphrey spirals on a barge, at the southern plant of the E. I. duPont de Nemours and Co. in Clay County, Fla.

beginning in Clay County and extending south-southeastward to the vicinity of Lake Okeechobee, but they were unsuccessful in locating a continuation of the paystreak. Although its northernmost limit is unknown, the Trail Ridge paystreak has been found in Florida and in Georgia east of the Okefenokee Swamp. The Trail Ridge deposit occurs at altitudes of 165-200 feet, and therefore appears to lie dominantly within the Coharie terrace, though some part of these ore sands may come from the underlying Hazlehurst terrace.

The thickness of the sands at the southern plant was measured in three wells drilled for water. These wells passed through 300 feet of sands, and 500 feet of limestone, presumably the Ocala Limestone. The hydrostatic head of the water in these wells is $140-170$ feet below the surface.

The ore minerals recovered at the two duPont plants are somewhat different in character and tenors from those at the plant of the National Lead Co. The principal minerals are ilmenite, leucoxene, rutile, zircon, and staurolite, which occur in mean ratios of about 12:2.5:1:5:7, respectively. The concentrates also contain sillimanite, kyanite, tourmaline, monazite, corundum, and traces of spinel, andalusite, garnet, and epidote. The four principal commercial products are ilmenite, a mixture of leucoxene and rutile, zircon, and staurolite. Leucoxene, which is 


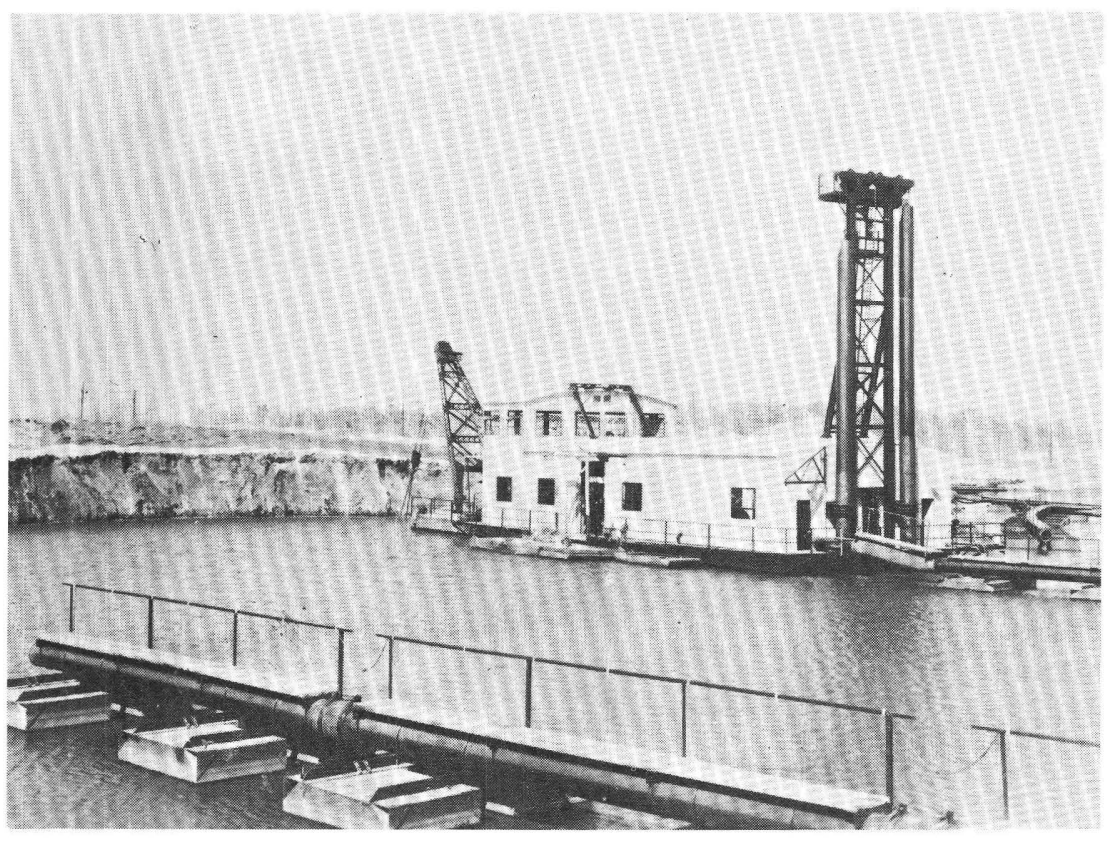

Figure 8. - Suction dredge of the E. I. duPont de Nemours and Co., at the southern plant in Clay County, Fla.

derived from ilmenite, has a magnetic susceptibility similar to that of rutile and thus cannot be separated from it. The mixture of these two minerals is called the ilmenite residue. The ratio of ilmenite to leucoxene is variable, ranging from $3: 1$ to $6: 1$, with a probable mean of about 5:1. Staurolite is recovered as an impure separate and is sold to a subsidiary of the Lehigh Portland Cement Co. at Bunnell, Fla., where it is used with Ocala Limestone in the manufacture of cement. This separate consists of about 75-80 percent staurolite, 10 percent tourmaline, and the remainder is mainly sillimanite, kyanite, and quartz. The tenor of monazite at Trail Ridge is reported to be only about 0.03 percent of the concentrates, or 0.001 percent of the ore sand. Its recovery would yield only a very small quantity.

The ilmenite and leucoxene found in Florida have both mineralogical and geological interest. Commercial partial analyses of ilmenite from the plants of the National Lead Co. and the E. I. duPont de Nemours and Co., together with the theoretical compositions of ilmenite and arizonite, are given in table 7 .

The chemical analyses indicate that the composition of this commercial ilmenite differs greatly from that of theoretical ilmenite. The high tenors in $\mathrm{TiO}_{2}$ have induced some of the operators in Florida to refer to their ilmenitic product as arizonite, but X-ray diffraction analyses give 
TABLE 7. - Composition, in percent, of minerals and ilmenite products from placer mines in Florida

\begin{tabular}{|c|c|c|c|c|}
\hline \multirow{2}{*}{ Oxides } & \multicolumn{2}{|c|}{ Theoretical composition } & \multicolumn{2}{|c|}{ Commercial ilmenite } \\
\hline & Ilmenite & Arizonite & National Lead Co. & duPont Co. \\
\hline \multirow{3}{*}{$\begin{array}{r}\mathrm{FeO}----------- \\
\mathrm{Fe}_{2} \mathrm{O}_{3}----------- \\
\mathrm{TiO}_{2}------------- \\
\text { Total }---------\end{array}$} & 47.35 & & 4.5 & 4.61 \\
\hline & $\overline{5} 2.6 \overline{5}$ & $\begin{array}{l}39.98 \\
60.02\end{array}$ & $\begin{array}{l}25.0 \\
64.0\end{array}$ & $\begin{array}{l}26.40 \\
61.50\end{array}$ \\
\hline & 100.00 & 100.00 & 93.5 & 92.51 \\
\hline
\end{tabular}

an ilmenite pattern. The high content of $\mathrm{Ti}_{2}$ suggests the presence of rutile, and the term "arizonite" is no longer accepted as a mineral species; arizonite is defined as a doubtful mineral (Fleischer, 1971, p. $5)$.

The $\mathrm{FeO}, \mathrm{Fe}_{2} \mathrm{O}_{3}$, and $\mathrm{TiO}_{2}$ contents of ilmenite in the duPont and National Lead placers are not substantially different (table 7), yet a considerable part of the ilmenite at duPont's Trail Ridge placer has been completely altered to leucoxene. At Trail Ridge, leucoxene is most plentiful in the upper horizons of the ore body and ilmenite and leucoxene are reported by the operators to occur as distinct minerals, without any intermediate products. Local conditions are probably responsible for the occurrence of leucoxene here. Leucoxene may have formed as a result of chemical alteration by ground water of detrital ilmenite after the ilmenite was deposited. The fallacy of this interpretation is that products intermediate between ilmenite and leucoxene should form, and these products are absent. Ilmenite at Trail Ridge could also be of two mineralogical types, one of which was readily altered to leucoxene, whereas the other was more resistant but was enriched in $\mathrm{Fe}_{2} \mathrm{O}_{3}$.

The ore sand at Trail Ridge is coarser and less well sorted than the sand at the plant of the National Lead Co., but the ore minerals are finer grained; as shown in table 8. Monazite has not been separated from these concentrates, and so the range in grain size has not been determined. All the monazite grains noted are smaller than 140 mesh, that is, less than $0.11 \mathrm{~mm}$ in size.

The placer on the west side of U.S. Highway 1 , about $71 / 2$ miles north-

TABLE 8. - Sizes of heavy minerals in concentrates from Trail Ridge, Fla.

[Data from E. I. duPont de Nemours and Co.]

\begin{tabular}{rcc}
\hline \multicolumn{2}{c}{ Grain size } & Percent \\
\hline Tyler standard mesh & Millimetres & \\
\hline+60 to +80 & $+0.22+--14$ \\
-80 to +100 & -0.22 to $+0.17----------$ & 22 \\
-100 to +140 & -0.17 to $+0.15--15$ to $+0.11----------$ & 27 \\
-140 & $-0.11------------$ & 9 \\
\hline
\end{tabular}


northwest of Vero Beach and just south of the city limits of Wabasso, has had a checkered history of mining. Prior to 1945, it was prospected independently by George A. Pritchard and Floyd Snow, but at that time it appeared to be too low grade for profitable mining. In 1954, however, the Florida Ore Processing Co., operating under lease by the Hobart Brothers Welding Co., began work on this deposit. In 1955, the Florida Minerals Co. was organized as a subsidiary of the Hobart Brothers Welding Co., and since that time has operated this property. In the initial stages of this operation, a suction dredge was used, but in 1957 this was replaced by a 2 -foot bucket dredge built by Hobart Brothers. This dredge was equipped with a concentrating plant consisting of a large number of linearly alined Cannon pinched sluices. The sand, which consists of 50 percent heavy minerals, is transported from the sluices by pipe to the main separatory plant, where the final concentration is completed on 14 Deister tables. The process in which the kilndried product is separated is similar to the separation of the concentrates at the National Lead Co. plant, except that two additional concentrating tables are used instead of spirals to separate zircon and monazite from other minerals of lower density. The plant of the Hobart Brothers Welding Co. is shown in figure 9.

The ore body, as originally mined, extended from the surface of the ground downward for about 20 feet, below which is a well-consolidated sand or hardpan 2-4 feet thick. The bucket dredge was designed to dig through the hardpan down to approximately sea level. This ore body had not been completely prospected in 1957, and so its length, width, and tenor were not accurately known. In 1956, the grade of heavy minerals was stated by the company to be $1 \frac{1 / 2-2}{\text { percent. The principal }}$ minerals recovered are ilmenite, rutile, and zircon; these comprise 65 percent of the heavy minerals, and occur in a mean ratio of $2.5: 1: 1$, respectively. Monazite is said to constitute about 0.2 percent of the concentrates, and it is recovered as a small byproduct.

The Hobart ore deposit is situated on a low, elongate ridge that extends as a marked topographic feature from the mouth of Sebastian Creek south-southeastward for 11 miles, passing west of Sebastian, Wabasso, and Winter Beach. This ridge is not continuous but is interrupted by a number of saddles. Its maximum height is west of Wabasso, where it attains an altitude of 52 feet; the other crests range in altitude from 35 to 45 feet. At the site of mining the altitude is about 40 feet, and the ore body appears to be part of the Talbot terrace.

A small ore body about half a mile south of Vero Beach was worked by the Riz Mineral Co., under the direction of George A. Pritchard, for several years after September 1943. This deposit had a workable length of about 1,500 feet, a minimum width of 200 feet, and a depth of from 10 to 12 feet. Below the ore body was a consolidated sand or hardpan. A dragline excavator was used in mining. The longitudinal and lateral ex- 


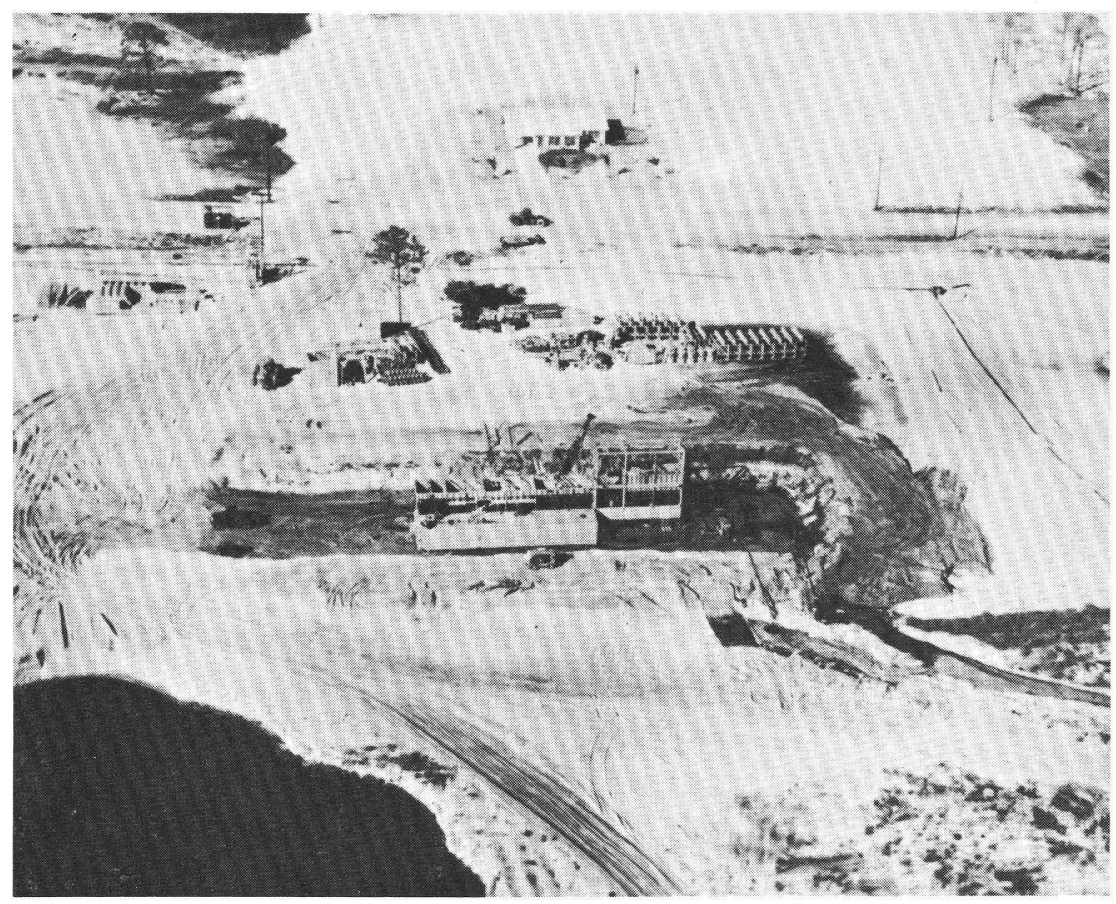

FIgURE 9. - Aerial view of the dredge, separatory plant, and offices of the Florida Minerals Co., looking east-northeast across U.S. Highway 1, Indian River County, Fla. Photography by Photocraft Commercial Studios, courtesy of Hobart Brothers Welding Co., 1957.

tent of the deposit were limited by the tenor in heavy minerals, which in the workable ground had a mean value of 5 percent.

The commercial minerals were ilmenite, rutile, and zircon, which occurred in a mean ratio of 2.5:1:1. Other minerals were staurolite, kyanite, tourmaline, epidote, garnet, monazite, spinel, and xenotime. This is the only reported occurrence of xenotime in the commercial operations of Florida. Monazite constituted 0.2 percent of the concentrates and, in the later stages of this operation, was saved as a small byproduct.

The sizes of the heavy minerals recovered at Vero Beach are not known, but a sample of the monazite was determined by me to have a range in grain sizes as shown in table 9. This monazite is finer grained than that at the plant of the National Lead Co. in Duval County.

The ore body occurs on a low elongate ridge at an altitude of 20-25 feet and is therefore considered to be a part of the Pamlico terrace.

Prospecting for heavy minerals was in progress during 1957 at a number of localities in Florida. The monazite content has been recorded at two of these localities. One of these sites is Amelia Island, along the northeast coast of Florida, at the mouth of St. Marys River, in 
TABLE 9. - Sizes of monazite grains from Vero Beach, Fla.

\begin{tabular}{ccc}
\hline \multicolumn{2}{c}{ Grain size } & \multirow{2}{*}{ Percent } \\
\hline Tyler standard mesh & Millimetres & \\
\hline-140 to +200 & -0.11 to $+0.074---------$ & 46.0 \\
-200 to +250 & -0.074 to $+0.061-0.0$ & 35.0 \\
-250 to +325 & -0.061 to $+0.043---------$ & 16.0 \\
-325 & $-0.043 \quad-----------$ & 3.0 \\
\hline
\end{tabular}

Nassau County. This island has been extensively prospected by several companies, and one company was preparing in 1957 to install a bucket dredge and separatory plant; but the decline in the metals markets, which began in August of that year, caused this project to be placed in abeyance. The mineral-bearing sand appears to lie mainly in the southern half of the island. The tenor in heavy minerals is reported to be about 3 percent, and monazite occurs in about the same tenor as at the property of the National lead Co. At the center of the island the paystreak trends about north and has an altitude of about 25 feet. Orebearing sands occur discontinuously eastward and westward to sea level. Hence, the mineral-bearing sands appear to lie within the Pamlico and Silver Bluff terraces. Talbot Island, in Duval County, and Anastasia Island, St. Johns County, have been prospected by other companies, but the results of the exploration are not known.

A large block of ground, about 5,000 acres acquired by the National Lead Co. in Duval County, north of Highland and east of Macclenny, appears to be the northern extension of the Trail Ridge paystreak. Also, the Bear Creek Mining Co. had been prospecting in Putnam and Clay Counties, Fla., but the results are unknown.

Considerable prospection has been done along the Gulf Coast of Florida. Prior to 1943, Stephen H. Rogers, of Tampa, acquired an option from the State of Florida to lease the sand deposits along the north shore of Santa Rosa Sound and along three bays east and northeast of Pensacola. These beach deposits, which were sampled by W. C. Hudson (1943, p. 13-15, 17-18), U.S. Bureau of Mines, were found to contain only a small volume of heavy minerals. Monazite was not reported from these deposits but could have been easily overlooked.

In 1954, 1955, and 1956, the Heavy Minerals Co., a subsidiary of the Crane Co., prospected the beach sands of the Gulf Coast of Florida, from 15 to 50 miles west of Panama City; but they did most of their work in Walton County between Phillips Inlet and Santa Rosa Sound. Workable deposits may occur behind a barrier dune that follows the coastline. The company claims that several large blocks of workable ground in this area have widths of 200-600 feet, and depths of 15-30 feet from the foot of the dunes to the outer edge of the beach.

The tenor in heavy minerals is reported to be about 3.5 percent. The 
principal ore minerals are ilmenite, rutile, and zircon, which compose about 62 percent of the concentrates and occur in the mean ratio of $3.2: 1: 1$, respectively. The concentrates also contain staurolite, kyanite, sillimanite, and monazite. The tenor in monazite according to one determination made by the company, was 0.16 percent of the concentrates. Little or no prospecting appears to have been done on the higher ground inland from the Gulf of Mexico.

Concentrations of heavy minerals have been reported at several sites along the west coast of Florida. One of these is at a prominent spit on the west side of Venice, where limestone is overlain by $6-8$ feet of sand. The lower 1-2 feet of sand is coarse pieces of comminuted shells. Above this, the sand is quartzose and the heavy minerals are concentrated in black carbonaceous layers. One of these beds, about 8 inches thick, was panned by me and was found to contain ilmenite, rutile, zircon, staurolite, and other minerals. Among the latter was a very small, but definitely recognizable, amont of monazite.

\section{CONCLUSIONS}

Exploration for fluviatile monazite placers in the Piedmont province of the Southeastern Atlantic States in the 1950's failed to disclose deposits that might be mined except under conditions of emergency demand for thorium and the rare earths. However, streams with thick sequences of gravel, such as might be found in the Blue Ridge, have not been investigated. They may contain workable monazite placers.

A fluviatile placer workable for monazite plus ilmenite, rutile, staurolite, and gravel has been mined at Horse Creek near Aiken, S. C. The source of the monazite is reworked sediments of Cretaceous and Tertiary age and monazite-bearing old granitic rocks at the Fall Line. Similar deposits are certainly present in similar geologic situations along the Fall Line in South Carolina and Georgia.

Placers associated with Pleistocene terrace deposits in the Coastal Plain of North Carolina, South Carolina, Georgia, and Florida have been shown to have small amounts of monazite associated with dominant ilmenite and other titanium minerals. Exploration for these deposits requires careful attention to geomorphic features because the surface expression of buried deposits is weak. A continuing industrial demand for the ores of titanium assures the continuing exploration for these deposits.

\section{REFERENCES CITED}

Bloomer, R. O., and Werner, H. J., 1955 Geology of the Blue Ridge region in central Virginia: Geol. Soc. America Bull., v. 66, no. 5, p. 579-606. 
Caldwell, D. W., 1962, Description, composition, and tenor of unconsolidated sediments in monazite-bearing tributaries to the Savannah and Saluda Rivers in the western Piedmont of South Carolina: U.S. Geol. Survey open-file rept., $19 \mathrm{p}$.

Caldwell, D. W., and White, A. M., 1973, Fluvial monazite deposits in the drainage basins of the Savannah and Saluda Rivers, South Carolina: South Carolina Div, Geology, Mineral Resources Ser. 2, 75 p.

Calver, J. L., 1957, Mining and mineral resources: Florida Geol. Survey Bull. 39, 132 p.

Carpenter, J. H., Detweiler, J. C., Jr., Gillson, J. L., Weichel, E. C., Jr., and Wood, J. P., 1953, Mining and concentration of ilmenite and associated minerals at Trail Ridge, Fla.: Mining Eng., v. 5, no. 8, p. 789-795.

Casperson, W. C., 1948, Heavy gravity minerals in the sands of Florida: Rocks and Minerals, v. 23 , no. 5 , p. $396-397$.

Cooke, C. W., 1945, Geology of Florida: Florida Geol. Survey Bull. 29, 339 p. 1954, Carolina bays and the shapes of eddies: U.S. Geol. Survey Prof. Paper 254-I, p. 195-207.

Cuppels, N. P., 1962, Description, composition, and tenor of unconsolidated sediments in monazite-bearing tributaries to the Enoree, Tyger, and Pacolet Rivers in the western Piedmont of South Carolina: U.S. Geol. Survey open-file rept., $17 \mathrm{p}$.

Cuppels, N. P., and White, A. M., 1973, Fluvial monazite deposits in the drainage basins of the Enoree, Tyger, and Pacolet Rivers, South Carolina: South Carolina Div. Geology, Mineral Resources Ser. 1, 74 p.

Davidson, C. F., 1957, On the occurrence of uranium in ancient conglomerates: Econ. Geology, v. 52, no. 6, p. 668-693.

Dryden, Lincoln, 1958, Monazite in part of the southern Atlantic Coastal Plain: U.S. Geol. Survey Bull. 1042-L, p. 393-429.

Emery, K. O., 1965, Some potential mineral resources of the Atlantic continental margin, in Geological Survey Research 1965: U.S. Geol. Survey Prof. Paper 525-C, p. C157-C160.

Fleischer, Michael, 1971, Glossary of mineral species: Bowie, Md., Mineralogical Records, Inc., $103 \mathrm{p}$.

Giese, F. P., Shirley, L. E., and Vallely, J. L., 1964, Titanium in the southeastern United States: U.S. Bur. Mines Inf. Circ. 8223, 30 p.

Griffith, R. F., and Overstreet, W. C., 1953a, Knob Creek monazite placer, Cleveland County, North Carolina: U.S. Atomic Energy Comm. Rept. RME-3112, 30 p. 1953b, Buffalo Creek monazite placer, Cleveland and Lincoln Counties, North Carolina: U.S. Atomic Energy Comm. Rept. RME-3113, 17 p.

1953c, Sandy Run Creek monazite placer, Rutherford County, North Carolina: U.S. Atomic Energy Comm. Rept. RME-3114, 27 p.

Hansen, L. A., and Caldwell, D. W., 1955, Monazite placers on Rabon Creek, Laurens County, and Big Generostee Creek, Anderson County, South Carolina: U.S. Atomic Energy Comm. Rept. RME-3118, 26 p.

Hansen, L. A., and Cuppels, N. P., 1954, Monzonite [Monazite] placer on the First Broad River and its tributaries, Cleveland County, North Carolina: U.S. Atomic Energy Comm. Rept. RME-3116, 27 p.

1955, Monazite placer at the junction of the North Tyger River with the Middle Tyger River, Spartanburg County, South Carolina: U.S. Atomic Energy Comm. Rept. RME-3117, 23 p.

Hansen, L. A., and Theobald, P. K., Jr., 1955, Monazite placers of the Broad River and Thicketty Creek, Cherokee County, South Carolina: U.S. Atomic Energy Comm. Rept. RME-3126, 30 p.

Hansen, L. A., and White, A. M., 1954, Monazite placers on South Muddy Creek, McDowell County, and Silver Creek, Burke County, North Carolina: U.S. Atomic Energy Comm. Rept. RME-3115, 28 p. 
Hudson, W. C., 1943, Beach sands near Pensacola; Santa Rosa, Escambia, and Okaloosa Counties, Florida: U.S. Bur. Mines War Minerals Rept. 141, 20 p.

Jones, W. H., 1949, The monazite-bearing sands of the Atlantic beaches: Mineralogist, v. 17 , no. 10 , p. $457-459$.

Kline, M. H., Griffith, R. F., and Hansen, L. A., 1954, Hollow Creek monazite placer, Aiken County, South Carolina: U.S. Atomic Energy Comm. Rept. RME-3127, 29 p.

Lamb, F. D., 1956, Rare-earth metals, in Mineral facts and problems: U.S. Bur. Mines Bull. 556, p. 735-743.

Lamcke, K., 1940, Natürliche Anreicherungen von Schwermineralien in Küstengebieten (2): Geol. der Meere u. Binnengewasser, v. 4, no. 1, p. 77-92.

Lenhart, W. B., 1956, Rare mineral recovery is the main business: Rock Products, v. 59, no. 9 , p. 62-69.

Liddell, D. M., 1917, A Florida rare-mineral deposit: Eng. and Mining Jour., v. 104, no. 4, p. $153-155$.

McCauley, C. K., 1960, Exploration for heavy minerals on Hilton Head Island, South Carolina: South Carolina Div. Geology Geol. Notes, v. 4, no. 4, 35 p.

Martens, J. H. C., 1928, Beach deposits of ilmenite, zircon, and rutile in Florida: Florida Geol. Survey 19th Ann. Rept., p. 124-154.

Mertie, J. B., Jr., 1953, Monazite deposits of the Southeastern Atlantic States: U.S. Geol. Survey Circ. 237, $31 \mathrm{p}$.

1957, Geologic occurrence of monazite and xenotime in the Southeastern States [abs.]: Geol. Soc. America Bull., v. 68, no. 12, pt. 2, p. 1766-1767.

Neiheisel, James, 1958a, Heavy mineral beach placers of the South Carolina coast: South Carolina Div. Geology, Mineral Industries Lab., Monthly Bull., v. 2, no. 1, p. 1-7. $1958 \mathrm{~b}$, Origin of the dune system on the Isle of Palms, South Carolina: South Carolina Div. Geology, Mineral Industries Lab., Monthly Bull., v. 2, no. 7, p. 46-51. 1959, Heavy minerals in South Carolina beach sands: South Carolina Div. Geology Bull., v. 3, no. 1, p. 90-91.

1962, Heavy-mineral investigation of Recent and Pleistocene sands of lower Coastal Plain of Georgia: Geol. Soc. America Bull., v. 73, no. 3, p. 365-374.

Overstreet, W. C., 1967, The geologic occurrence of monazite: U.S. Geol. Survey Prof. Paper 530, $327 \mathrm{p}$.

Overstreet, W. C., Cuppels, N. P., and White, A. M., 1956, Monazite in Southeastern States, in Internat. Conf. Peaceful Uses Atomic Energy, Geneva 1955, Proc.: v. 6, p. 593-596.

Overstreet, W. C., Theobald, P. K., Jr., and Whitlow, J. W., 1959, Thorium and uranium resources in monazite placers of the western Piedmont, North and South Carolina: Mining Eng., v. 11, no. 7, p. 709-714.

Overstreet, W. C., White, A. M., Theobald, P. K., Jr., and Caldwell, D. W., 1971, Selected fluvial monazite deposits in the Southeastern United States: U.S. Geol. Survey open-file rept., 108 p., 4 pls., 1 fig., 17 tables.

Overstreet, W. C., White, A. M., and Warr, J. J., Jr., 1970, Uranium-rich monazites in the United States, in U.S. Geological Survey research 1970: U.S. Geol. Survey Prof. Paper 700-D, p. D169-D175.

Overstreet, W. C., White, A. M., Whitlow, J. W., Theobald, P. K., Jr., Caldwell, D. W., and Cuppels, N. P., 1968, Fluvial monazite deposits in the southeastern United States: U.S. Geol. Survey Prof. Paper 568, 85 p.

Overstreet, W. C., Yates, R. G., and Griffitts, W. R., 1963, Heavy accessory minerals in the saprolite of the crystalline rocks in the Shelby quadrangle, North Carolina: U.S. Geol. Survey Bull. 1162-F, 31 p.

Parker, J. G., and Baroch, C. T., 1971, The rare-earth elements, yttrium, and thorium, with a chapter on Resources, by J. W. Adams: U.S. Bur. Mines Inf. Circ. 8476, 92 p. 
Pepper, J. F., 1958, Potential mineral resources of the continental shelves of the western hemisphere, in Trumbull, J. V., An introduction to the geology and mineral resources of the continental shelves of the Americas: U.S. Geol. Survey Bull. 1067, p. 43-65.

Pilkey, O. H., 1963, Heavy minerals of the U.S. South Atlantic continental shelf and slope: Geol. Soc. America Bull., v. 74, no. 5, p. 641-648.

Rove, O. N., 1952, Mining geology: Mining Eng., v. 4, no. 2, p. 140-143.

Shepard, C. U., 1849, Notices of American minerals: Am. Jour. Sci., ser. 2, v. 8, no. 23, p. 274-275.

1852, A treatise on mineralogy, [3d ed.]: New Haven, B. L. Hamlen, 451 p.

Smith, J. W., Pickering, S. M., Jr., and Landrum, J. R., 1967, Heavy-mineral-bearing sand of the coastal region of Georgia: Georgia Dept. Mines, Mining and Geology, South Georgia Minerals Program Proj. Rept. 8, 68 p.

Spencer, R. V., 1948, Titanium minerals in Trail Ridge, Florida: U.S. Bur. Mines Rept. Inv. $4208,21 \mathrm{p}$.

Tanner, W. F., Mullins, Allan, and Bates, J. D., 1961, Possible masked heavy-mineral deposit, Florida Panhandle: Econ. Geology, v. 56, no. 6, p. 1079-1087.

Theobald, P. K., Jr., 1962, Description, composition, and tenor of unconsolidated sediments in monazite-bearing tributaries to the Broad River in the western Piedmont of South Carolina and North Carolina: U.S. Geol. Survey open-file rept., 18 p.

Trumbull, James, Lyman, John, Pepper, J. F., and Thomasson, E. M., 1958, An introduction to the geology and mineral resources of the continental shelves of the Americas: U.S. Geol. Survey Bull. 1067, 92 p.

Tyler, S. A., 1934, A study of sediments from the North Carolina and Florida coasts: Jour. Sed. Petrology, v. 4, no. 1, p. 3-11.

U.S. Geological Survey, 1970, The National atlas of the United States of America: Washington, D. C., $417 \mathrm{p}$.

Weeks, M. E., 1956, Discovery of the elements [6th ed.]: Easton, Pa., Jour. Chem. Ed., $910 \mathrm{p}$.

White, A. M., 1962, Description, composition, and tenor of unconsolidated sediments in monazite-bearing tributaries to the Catawba River in the western Piedmont of North Carolina: U.S. Geol. Survey open-file rept., 17 p.

Williams, Lloyd, 1964, Titanium deposits in North Carolina: North Carolina Dept. Conserv. and Devel. Div. Mineral Resources Inf. Circ. 19, 51 p.

1967, Heavy minerals in South Carolina: South Carolina Div. Geology Bull. 35, 35 p.

Williams, R. M., 1969, Uranium and thorium, in Canadian Minerals Yearbook 1967: Canada Dept. Energy, Mines and Resources Mineral Resources Br. Mineral Rept. 17, p. $479-489$. 





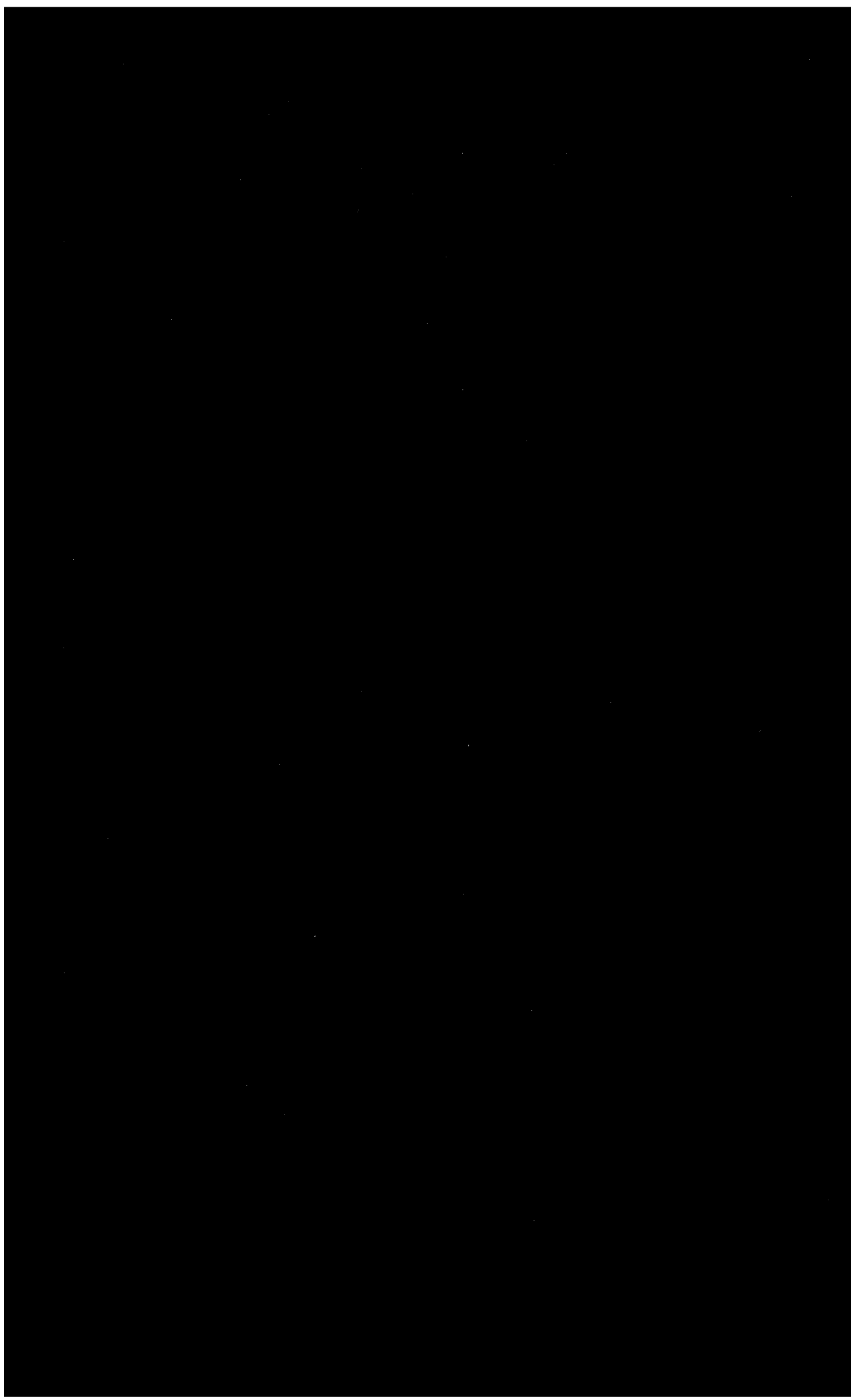




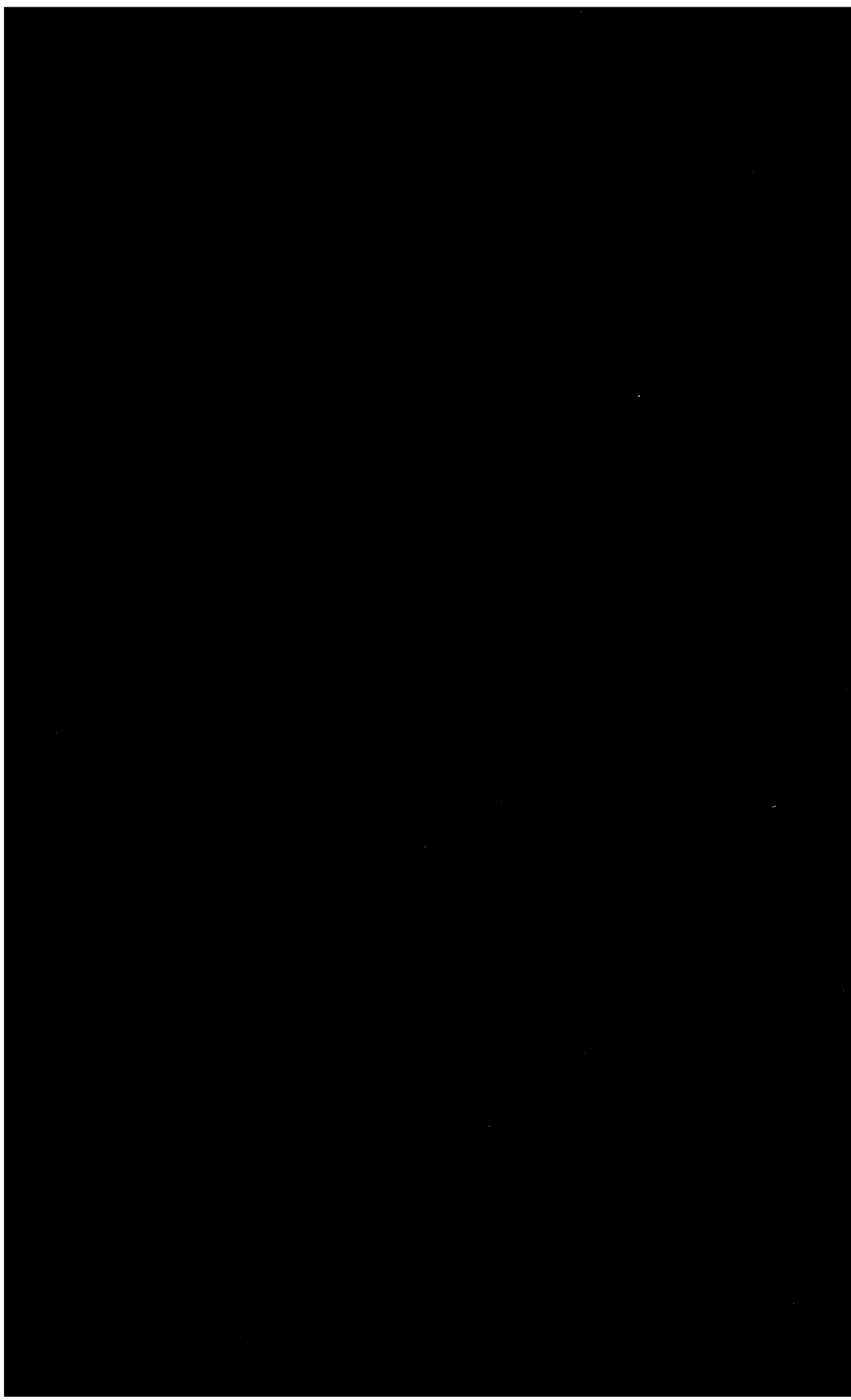

